\title{
Transactions
}

Cite this: Dalton Trans., 2011, 40, 9690

wWW.rsc.org/dalton

PAPER

\section{Effect of substitution and planarity of the ligand on DNA/BSA interaction, free radical scavenging and cytotoxicity of diamagnetic Ni(II) complexes: $\mathrm{A}$ systematic investigation $\uparrow$}

\author{
Palanisamy Sathyadevi, ${ }^{a}$ Paramasivam Krishnamoorthy, ${ }^{a}$ Rachel R. Butorac, ${ }^{b}$ Alan H. Cowley, ${ }^{b}$ \\ Nattamai S. P. Bhuvanesh ${ }^{c}$ and Nallasamy Dharmaraj*a
}

Received 27th April 2011, Accepted 24th June 2011

DOI: $10.1039 /$ c1dt10767d

Four new bivalent nickel hydrazone complexes have been synthesised from the reactions of $\left[\mathrm{NiCl}_{2}\left(\mathrm{PPh}_{3}\right)_{2}\right]$ with $\mathrm{H}_{2} \mathrm{~L}\{\mathrm{~L}=$ dianion of the hydrazones derived from the condensation of salicylaldehyde or $o$-hydroxy acetophenone with $p$-toluic acid hydrazide $\left(\mathrm{H}_{2} \mathrm{~L}^{1}\right)(\mathbf{1}),\left(\mathrm{H}_{2} \mathrm{~L}^{2}\right)(\mathbf{2})$ and $o$-hydroxy acetophenone or $o$-hydroxy naphthaldehyde with benzhydrazide $\left(\mathrm{H}_{2} \mathrm{~L}^{3}\right)(3)$ and $\left.\left(\mathrm{H}_{2} \mathrm{~L}^{4}\right)(\mathbf{4})\right\}$ and formulated as $\left[\mathrm{Ni}\left(\mathrm{L}^{1}\right)\left(\mathrm{PPh}_{3}\right)\right](5),\left[\mathrm{Ni}\left(\mathrm{L}^{2}\right)\left(\mathrm{PPh}_{3}\right)\right](\mathbf{6}),\left[\mathrm{Ni}\left(\mathrm{L}^{3}\right)\left(\mathrm{PPh}_{3}\right)\right](7)$ and $\left[\mathrm{Ni}\left(\mathrm{L}^{4}\right)\left(\mathrm{PPh}_{3}\right)\right](8)$. Structural characterization of complexes 5-8 were accomplished by using various physico-chemical techniques. In order to study the influence of substitution in the ligand and its planarity on the biological activity of complexes 5-8 containing them, suitable hydrazone ligands $\mathbf{1}-\mathbf{4}$ have been selected in this study. Single crystal diffraction data of complexes 5, 7 and $\mathbf{8}$ proved the geometry of the complexes to be distorted square planar with a $1: 1$ ratio between the metal ion and the coordinated hydrazones. To provide more insight on the mode of action of complexes 5-8 under biological conditions, additional experiments involving their interaction with calf thymus DNA (CT DNA) and bovine serum albumin (BSA) were monitored by UV-visible and fluorescence titrations respectively. Further, the ligands 1-4 and corresponding nickel(II) chelates 5-8 have been tested for their scavenging effect towards $\mathrm{OH}$ and $\mathrm{O}_{2}{ }^{-}$radicals. The effect of complexes 5-8 to arrest the growth of HeLa and Hep-2 tumour cell lines has been studied along with the cell viability against the non-cancerous NIH $3 \mathrm{~T} 3$ cells under in vitro conditions.

\section{Introduction}

Transition metal chelates that play a key role in bio-inorganic chemistry and redox enzyme systems serve as the basis of models for active sites in biologically important compounds. Despite many efforts in trying to unravel the role of metal ions in biology, much remains to be learned about how these metal

'Department of Chemistry, Bharathiar University, Coimbatore, 641046 , India. E-mail: dharmaraj@buc.edu.in; Fax: +91422 2422387; Tel: +91 422 2428316

${ }^{b}$ Department of Chemistry and Biochemistry, University of Texas at Austin, Austin, Texas, 78712, U.S.A

'Department of Chemistry, Texas A\&M University, College Station, TX 77843 , U.S.A

$\dagger$ Electronic supplementary information (ESI) available: Crystal packing diagram of the unit cell of complexes 5, 7 and $\mathbf{8}$ (Figures S1, S2 and S3), Electronic absorption spectra of binding of complexes 5, 6 and 7 with DNA (Figures S4, S5 and S6), Emission spectra of DNA-EB in the presence of complexes 5, 6 and 7 (Figures S7, S8 and S9), Emission spectra of binding of complexes 5, 6 and 7 with BSA (Figures S10, S11 and S12), Absorption spectra of binding of complexes 5, $\mathbf{6}$ and $\mathbf{7}$ with BSA (Figures S13, S14 and $\mathrm{S} 15)$, Synchronous spectra $(\Delta \lambda=15$ and $60 \mathrm{~nm})$ of binding of complexes 5 , 6 and 7 with BSA (Figures S16, S17 and S18). CCDC reference numbers 751231, 780528 and 822887. For ESI and crystallographic data in CIF or other electronic format see DOI: 10.1039/cldt10767d cations are trafficked and stored prior to their incorporation into different metalloproteins. ${ }^{1}$ Metal chelation is an excellent ways to increase the lipophilic character of the organic moiety. In fact, on coordination, ligands might improve their bioactivity profiles, while some inactive ligands may acquire pharmacological properties and consequently they have become an important class of structure-selective binding agents for nucleic acids. Compounds that can selectively recognize a non-duplex structure involved in the control of gene expression have considerable potential as chemotherapeutic agents for a variety of diseases. Metal complexes can interact with non-duplex structures through the same mechanisms as duplex DNA and RNA, i.e. covalent binding, intercalation and groove binding.

Among these DNA-targeted guest molecules, ruthenium, cobalt and copper complexes are numerous in the literature. ${ }^{2-5}$ Though nickel is an essential element related to life process and an active component in various types of enzymes, studies on the interactions of nickel(II) complexes with DNA are comparably less. ${ }^{6-8}$ In recent years, reports on the role of nickel in bioinorganic chemistry have been rapidly expanding. The interaction of nickel(II) complexes with DNA has been mainly dependent on the structure of the ligand exhibiting intercalative behavior and/or DNA cleavage 
ability. ${ }^{9-13}$ Particulate nickel compounds (such as $\mathrm{Ni}_{2} \mathrm{~S}_{3}$ ) enter a cell by phagocytosis, find their way to the nucleus, and cause oxidative DNA strand breaks, DNA-DNA cross-links and DNAprotein cross-links. ${ }^{14-17}$ The mechanism by which this occurs is of considerable interest not only to toxicologists investigating carcinogenesis, but also to chemists designing DNA targeted drugs.

Proteins play an important role in transportation and deposition of endogenous and exogenous substances such as fatty acids, harmones and medicinal drugs. Drug interactions at the protein binding level will significantly affect the apparent distribution volume of the drugs and also the elimination rate of drugs. Therefore, studies on this aspect are undertaken with a view to derive some vital information regarding the structural features that determine the therapeutic effectiveness of a drug, and have been an interesting research field in life sciences, chemistry and clinical medicine. ${ }^{18}$ Studies on the binding of albumins from blood plasma with pyridoxal phosphate, cystein, glutathione, Schiff bases, various metal ions such as $\mathrm{Cu}(\mathrm{II}), \mathrm{Ni}(\mathrm{II}), \mathrm{Mn}(\mathrm{II}), \mathrm{Co}(\mathrm{II}), \mathrm{Hg}(\mathrm{II}), \mathrm{Zn}$ (II), metal complexes and metal-binding metallothionein proteins are reported in the literature. Although studies have been carried out to understand the interaction of metal complexes, metal ions and Schiff base ligands with albumins, corresponding investigations on nickel hydrazone complexes seems to be scanty. ${ }^{19-27}$

Based on the above facts and considering the role and activity of nickel and its complexes in biological systems, along with the significance of hydrazones in medicine, we present in this work a systematic study on the synthesis and molecular structure of nickel(II) complexes containing hydrazone ligands and their interaction with nucleic acids (DNA) and proteins, along with cytotoxicity and antioxidant assays. Further, the effect of the substituent group present on the ligand as well as planarity of the molecule on the above said properties were also studied in detail.

\section{Experimental section}

\section{Materials and reagents}

Reagent grade chemicals $\mathrm{NiCl}_{2} \cdot 6 \mathrm{H}_{2} \mathrm{O}$, triphenylphosphine, salicylaldehyde, $o$-hydroxy acetophenone, $o$-hydroxy napthaldehyde, benzhydrazide and $p$-toluic hydrazide were purchased from
Sigma-Aldrich and used as received. All the chemicals and reagents used for DNA binding, protein binding, antioxidant and cytotoxicity assays were of high quality and available from reputed suppliers.

\section{Synthesis of ligands (1-4) and corresponding nickel hydrazone complexes (5-8)}

The reactions involved in the synthesis of hydrazone ligands and corresponding nickel complexes are given in Scheme 1.

Synthesis of nickel precursor complex. The precursor metal complex $\left[\mathrm{NiCl}_{2}\left(\mathrm{PPh}_{3}\right)_{2}\right]$ was prepared according to the literature method. ${ }^{28}$

Synthesis of [4-methyl-benzoic acid (2-hydroxy-benzylidene)hydrazide] $\left(\mathbf{H}_{2} \mathbf{L}^{1}\right) \mathbf{~ ( 1 ) . ~ T h e ~ l i g a n d ~ 4 - m e t h y l - b e n z o i c ~ a c i d ~ ( 2 - ~}$ hydroxy-benzylidene)-hydrazide (1) was prepared by refluxing a mixture of salicylaldehyde $(0.122 \mathrm{~g} ; 1 \mathrm{mM})$ and $p$-toluic hydrazide $(0.150 \mathrm{~g} ; 1 \mathrm{mM})$ in $50 \mathrm{~mL}$ of absolute ethanol for $8 \mathrm{~h}$ as given in Scheme 1 . The reaction mixture was cooled to room temperature and the solid obtained was filtered, washed several times with distilled water and recrystallized from $\mathrm{EtOH}$ to afford ligand 1 in pure form with $85 \%$ yield. Anal. Found $(\%)$ for $\mathrm{C}_{15} \mathrm{H}_{14} \mathrm{~N}_{2} \mathrm{O}_{2}$ (Mol. wt $=$ 254.28): C, 70.93\%; H, 5.32\%; N, 11. 27\%. Calculated (\%) for C, $70.85 \%$; H, 5.55\%; N, 11.02\%. Selected IR bands $\left(v\right.$ in $\left.\mathrm{cm}^{-1}\right): 3388$ (phenolic, $-\mathrm{OH}) ; 3215(-\mathrm{NH}) ; 1622(>\mathrm{C}=\mathrm{O}) ; 1572(>\mathrm{C}=\mathrm{N}-)$; $1035(=\mathrm{N}-\mathrm{N}<) ; 1270$ (phenolic, $\mathrm{C}-\mathrm{OH}) .{ }^{1} \mathrm{H}$ NMR $\left(\mathrm{DMSO}^{-D_{6}}\right.$, ppm): $12.10(\mathrm{~s}, 1 \mathrm{H},-\mathrm{OH}) ; 11.20(\mathrm{~s}, 1 \mathrm{H},-\mathrm{NH}) ; 8.24(\mathrm{~s}, 1 \mathrm{H},-$ $\mathrm{CH}=\mathrm{N}-)$; 7.84-6.88 (m, 8H, Ar-H); $2.44\left(\mathrm{~s}, 3 \mathrm{H},-\mathrm{CH}_{3}\right)$.

Synthesis of [4-methyl-benzoic acid [1-(2-hydroxy-phenyl)ethylidenel-hydrazide] $\left(\mathbf{H}_{2} \mathbf{L}^{2}\right) \mathbf{( 2 )}$. Ligand $\mathbf{2}$ was prepared by a procedure similar to the one described above utilizing $o$ hydroxyacetophenone $(0.136 \mathrm{~g} ; 1 \mathrm{mM})$ and $p$-toluic hydrazide $(0.150 \mathrm{~g} ; 1 \mathrm{mM})$ (Scheme 1). Anal. Found (\%) for $\mathrm{C}_{16} \mathrm{H}_{16} \mathrm{~N}_{2} \mathrm{O}_{2}$ (Mol. wt = 268.31): C, 71.93\%; H, 6.12\%; N, 10.77\%. Calculated $(\%)$ for C, 71.62\%; H, 6.01\%; N, 10.44\%. Selected IR bands $(v$ in $\left.\mathrm{cm}^{-1}\right): 3342$ (phenolic, $\left.-\mathrm{OH}\right) ; 3206(-\mathrm{NH}) ; 1661(>\mathrm{C}=\mathrm{O})$; 1608( $>\mathrm{C}=\mathrm{N}-$ ); $1005(=\mathrm{N}-\mathrm{N}<)$; 1269 (phenolic, $\mathrm{C}-\mathrm{OH}) .{ }^{1} \mathrm{H}$ NMR (DMSO-D 6 , ppm): $12.72(\mathrm{~s}, 1 \mathrm{H},-\mathrm{OH}) ; 8.94(\mathrm{~s}, 1 \mathrm{H},-\mathrm{NH})$; 7.78-6.90 (m, 8H, Ar-H); $2.46\left(\mathrm{~s}, 3 \mathrm{H}, \mathrm{CH}_{3} \mathrm{C}=\mathrm{N}-\right)$; $2.42(\mathrm{~s}, 3 \mathrm{H}$, $\left.-\mathrm{CH}_{3}\right)$.

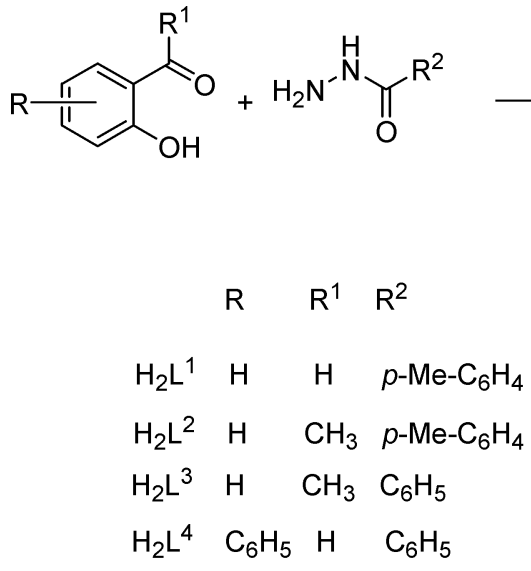<smiles>[R]C(=O)NN=C([R])c1c[R](-c2ccc(O)c(C([R1])=NN=C([R])O)c2)ccc1O</smiles>

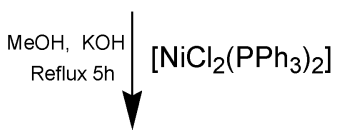<smiles>[R]C1=NN2N=C([R])c3cc([R])ccc3O[N+]2(P)O1</smiles>

Scheme 1 
Synthesis of [benzoic acid [1-(2-hydroxy-phenyl)-ethylidene]hydrazidel $\left(\mathbf{H}_{2} \mathbf{L}^{3}\right)$ (3). Ligand 3 was prepared using a similar procedure as described above with $o$-hydroxyacetophenone $(0.136 \mathrm{~g}$; $1 \mathrm{mM})$ and benzhydrazide $(0.136 \mathrm{~g} ; 1 \mathrm{mM})$ as suitable reactants. (Scheme 1). Anal. Found (\%) for $\mathrm{C}_{15} \mathrm{H}_{14} \mathrm{~N}_{2} \mathrm{O}_{2}$ (Mol. wt $=254.28$ ): C, $69.93 \% ; \mathrm{H}, 4.32 \% ; \mathrm{N}, 14.27 \%$. Calculated $(\%)$ for C, $70.85 \%$; , $5.55 \%$; N, 11.02\%. Selected IR bands $\left(v\right.$ in $\left.\mathrm{cm}^{-1}\right): 3328$ (phenolic, $-\mathrm{OH}) ; 3213(-\mathrm{NH}) ; 1649(>\mathrm{C}=\mathrm{O}) ; 1605(>\mathrm{C}=\mathrm{N}-) ; 1026(=\mathrm{N}-$ $\mathrm{N}<$ ); 1269 (phenolic, C-OH). ${ }^{1} \mathrm{H}$ NMR (DMSO-D $\left.{ }_{6}, \mathrm{ppm}\right): 13.32$ (s, $1 \mathrm{H},-\mathrm{OH}) ; 11.30(\mathrm{~s}, 1 \mathrm{H},-\mathrm{NH}) ; 7.94-6.87$ (m, 9H, Ar-H); 2.49 (s, $3 \mathrm{H}, \mathrm{CH}_{3} \mathrm{C}=\mathrm{N}-$ ).

Synthesis of [benzoic acid(3-hydroxy-naphthalen-2-ylmethylene)hydrazide] $\left(\mathbf{H}_{2} \mathbf{L}^{4}\right)$ (4). As described in the above cases, ligand $\mathbf{4}$ was prepared from $o$-hydroxynaphthaldehyde $(0.172 \mathrm{~g} ; 1 \mathrm{mM})$ and benzhydrazide ( $0.136 \mathrm{~g} ; 1 \mathrm{mM}$ ) (Scheme 1). Anal. Found (\%) for $\mathrm{C}_{18} \mathrm{H}_{14} \mathrm{~N}_{2} \mathrm{O}_{2}$ (Mol. wt = 290.31): C, 69.93\%; H, 4.32\%; N, 14 . $27 \%$. Calculated (\%) for C, 74.47\%; H, 4.86\%; N, 9.65\%. Selected IR bands $\left(v\right.$ in $\left.\mathrm{cm}^{-1}\right)$ : 3486 (phenolic, $\left.-\mathrm{OH}\right) ; 3223(-\mathrm{NH}) ; 1616$ $(>\mathrm{C}=\mathrm{O}) ; 1570(>\mathrm{C}=\mathrm{N}-) ; 1030(=\mathrm{N}-\mathrm{N}<) ; 1290$ (phenolic, $\mathrm{C}-$ $\mathrm{OH}) .{ }^{1} \mathrm{H}$ NMR (DMSO-D 6 , ppm): 12.76 (s, $\left.1 \mathrm{H},-\mathrm{OH}\right) ; 12.18$ (s, $1 \mathrm{H},-\mathrm{NH}) ; 9.49(\mathrm{~s}, 1 \mathrm{H}, \mathrm{CH}=\mathrm{N}-)$; 8.22-7.22 (m, 11H, $\mathrm{Ar}-\mathrm{H})$.

Synthesis of the new nickel(II) hydrazone complex $\left[\mathrm{Ni}\left(\mathrm{L}^{1}\right)\left(\mathrm{PPh}_{3}\right)\right]$ (5). Complex 5 was synthesised by refluxing a methanolic solution of $\left[\mathrm{NiCl}_{2}\left(\mathrm{PPh}_{3}\right)_{2}\right](0.653 \mathrm{~g} ; 1 \mathrm{mM})$ and ligand $\mathbf{1}(0.254 \mathrm{~g}$; $1 \mathrm{mM})(40 \mathrm{~mL})$ in the presence of $\mathrm{KOH}$ (Scheme 1) for $5 \mathrm{~h}$. After cooling the reaction mixture to room temperature, the precipitate formed was filtered, washed with methanol and dried in vacuo. The purity of the complex was checked by TLC, following which tetragonal shaped crystals of complex $\mathbf{5}$ suitable for single-crystal $\mathrm{X}$-ray diffraction studies were obtained by recrystallisation in dichloromethane. Yield: $58 \%$, Color: red, mp: $220^{\circ} \mathrm{C}$. Anal. Found (\%) for $\mathrm{NiC}_{34} \mathrm{H}_{30} \mathrm{~N}_{2} \mathrm{O}_{2} \mathrm{P}($ Mol. Wt. = 588.28): C, 57.24\%; H, 4.81\%; N, $11.52 \%$. Calculated (\%) for C, $69.42 \%$; H, $5.14 \%$; N, $4.76 \%$. Selected IR bands $\left(v\right.$ in $\left.\mathrm{cm}^{-1}\right): 1597 \& 1501(>\mathrm{C}=\mathrm{N}-\mathrm{N}=\mathrm{C}<)$; 1336 (phenolic $-\mathrm{C}-\mathrm{O}$ ); 1302 (enolic $-\mathrm{C}-\mathrm{O}) ; 1099(=\mathrm{N}-\mathrm{N}=) .{ }^{1} \mathrm{H}$ NMR (DMSO-D, ppm): $8.31(\mathrm{~s}, 1 \mathrm{H}, \mathrm{HC}=\mathrm{N}-) ; 7.85-6.52(\mathrm{~m}$, $23 \mathrm{H}, \mathrm{Ar}-\mathrm{H}) ; 2.31\left(\mathrm{~s}, 3 \mathrm{H},-\mathrm{CH}_{3}\right)$.

Synthesis of $\left[\mathbf{N i}\left(\mathrm{L}^{2}\right)\left(\mathbf{P P h}_{3}\right)\right]$ (6). Complex $\mathbf{6}$ was prepared by a procedure similar to that given in the case of $\mathbf{5}$, from $\left[\mathrm{NiCl}_{2}\left(\mathrm{PPh}_{3}\right)_{2}\right]$ $(0.653 \mathrm{~g} ; 1 \mathrm{mM})$ and ligand $2(0.268 \mathrm{~g} ; 1 \mathrm{mM})$ as reactants. The work-up of the reaction mixture did not yield any crystals suitable for single crystal XRD and hence this was not recorded. Yield: $55 \%$, Color: red, mp: $212^{\circ} \mathrm{C}$. Anal. Found (\%) for $\mathrm{NiC}_{35} \mathrm{H}_{32} \mathrm{~N}_{2} \mathrm{O}_{2}$ (Mol. wt. $=602.30)$ C, 61.94\%; H, 3.91\%; N, 12.96\%. Calculated (\%) for C, 69.79\%; H, 5.36\%; N,4.65\%. Selected IR bands ( $v$ in $\left.\mathrm{cm}^{-1}\right)$ : $1579 \& 1532(>\mathrm{C}=\mathrm{N}-\mathrm{N}=\mathrm{C}<$ ); 1356 (phenolic $-\mathrm{C}-$ O); 1306 (enolic -C-O); $1098\left(=\mathrm{N}-\mathrm{N}=\right.$ ). ${ }^{1} \mathrm{H}$ NMR (DMSO-D ${ }_{6}$, ppm): 7.75-6.40 (m, 23H, $\mathrm{Ar}-\mathrm{H}) ; 2.52\left(\mathrm{~s}, 3 \mathrm{H}, \mathrm{CH}_{3} \mathrm{C}=\mathrm{N}-\right) ; 2.41$ $\left(\mathrm{s}, 3 \mathrm{H},-\mathrm{CH}_{3}\right.$ ).

Synthesis of $\left[\mathbf{N i}\left(\mathbf{L}^{3}\right)\left(\mathbf{P P h}_{3}\right)\right]$ (7). Reaction of $\left[\mathrm{NiCl}_{2}\left(\mathrm{PPh}_{3}\right)_{2}\right]$ $(0.653 \mathrm{~g} ; 1 \mathrm{mM})$ with ligand $3(0.254 \mathrm{~g} ; 1 \mathrm{mM})$ under identical experimental conditions as reported for the synthesis of complex 5 yielded tetragonal shaped crystals of complex 7 which were analysed by single crystal XRD. Yield: $59 \%$, Color: red, mp: $208{ }^{\circ} \mathrm{C}$. Anal. Found (\%) for $\mathrm{NiC}_{34} \mathrm{H}_{30} \mathrm{~N}_{2} \mathrm{O}_{2}$ (Mol. wt. $=588.28$ ) C, $61.94 \%$; H, 3.91\%; N, $12.96 \%$. Calculated (\%) for C, $69.42 \%$; H, $5.14 \%$; N, $4.76 \%$. Selected IR bands $\left(v\right.$ in cm $\left.{ }^{-1}\right): 1574$ \& 1527
$(>\mathrm{C}=\mathrm{N}-\mathrm{N}=\mathrm{C}<$ ); 1346 (phenolic $-\mathrm{C}-\mathrm{O}) ; 1329$ (enolic $-\mathrm{C}-\mathrm{O}$ ); $1094(=\mathrm{N}-\mathrm{N}=) .{ }^{1} \mathrm{H}$ NMR (DMSO-D 6 , ppm): 7.82-6.57 (m, 24H, $\mathrm{Ar}-\mathrm{H}) ; 2.54$ (s, $3 \mathrm{H}, \mathrm{CH}_{3}-\mathrm{C}=\mathrm{N}-$ ).

Synthesis of $\left[\mathbf{N i}\left(\mathrm{L}^{4}\right)\left(\mathbf{P P h}_{3}\right)\right]$ (8). Complex $\mathbf{8}$ was also prepared in a manner similar to that mentioned in the previous cases by treating $\left[\mathrm{NiCl}_{2}\left(\mathrm{PPh}_{3}\right)_{2}\right](0.653 \mathrm{~g} ; 1 \mathrm{mM})$ with ligand $4(0.290 \mathrm{~g}$; $1 \mathrm{mM}$ ). However, the reaction mixture after work-up afforded needle like violet crystals of complex $\mathbf{8}$ which were analysed through single crystal XRD to determine its geometry. Yield: $53 \%$, Color: violet, mp: $180{ }^{\circ} \mathrm{C}$. Anal. Found (\%) for $\mathrm{NiC}_{37} \mathrm{H}_{30} \mathrm{~N}_{2} \mathrm{O}_{2}$ (Mol. wt. = 624.31) C, 61.94\%; H, 3.91\%; N, 12.96\%. Calculated (\%) for C, $71.18 \%$; H, 4.84\%; N, 4.49\%. Selected IR bands ( $v$ in $\left.\mathrm{cm}^{-1}\right)$ : $1597 \& 1530(>\mathrm{C}=\mathrm{N}-\mathrm{N}=\mathrm{C}<$ ); 1345 (phenolic $-\mathrm{C}-$ O); 1328 (enolic $-\mathrm{C}-\mathrm{O}) ; 1095(=\mathrm{N}-\mathrm{N}=){ }^{1} \mathrm{H}$ NMR (DMSO-D ${ }_{6}$, ppm): $9.62(\mathrm{~s}, 1 \mathrm{H},-\mathrm{CH}=\mathrm{N}-) ; 8.18-6.61(\mathrm{~m}, 26 \mathrm{H}, \mathrm{Ar}-\mathrm{H})$.

\section{Physical measurements and instrumentation}

Elemental analyses ( $\% \mathrm{C}, \mathrm{H} \& \mathrm{~N})$ were performed on a Vario EL III CHNS analyzer and all IR spectra were recorded as $\mathrm{KBr}$ pellets on a Nicolet Avatar instrument in the frequency range $400-4000 \mathrm{~cm}^{-1}$. Both electronic and fluorescence spectra of the complexes were recorded in DMSO: buffer $(1: 99)$ using Jasco V-630 spectrophotometer and Jasco FP 6600 spectrofluorometer respectively. ${ }^{1} \mathrm{H}$ NMR spectra of the ligands and corresponding nickel(II) complexes were recorded on a Bruker AMX $500 \mathrm{MHz}$ spectrometer using tetramethylsilane as an internal standard and DMSO as a solvent. The X-ray diffraction data of complexes $\mathbf{5}$ and 7, were collected at 100 and $293 \mathrm{~K}$ respectively with Mo-K $\alpha$ radiation $(\lambda=0.71075$ and $0.71073 \AA$ ) using a Bruker Smart APEX II CCD diffractometer equipped with a graphite monochromator. The structures were solved by direct methods and refined fullmatrix least squares (on $\mathrm{F}^{2}$ ) SHELXS97 and SHELXL97 ${ }^{29}$ and the graphics were produced using PLATON97. ${ }^{30}$ All the nonhydrogen atoms were refined anisotropically and the hydrogen atoms were positioned geometrically and refined as riding model. The XRD data of the complex 8 was collected at $110 \mathrm{~K}$ with $\mathrm{Cu}-\mathrm{K} \alpha$ radiation $\lambda=1.5418$ using a BRUKER GADDS X-ray (three-circle) diffractometer. The structure was refined (weighted least squares refinement on $F^{2}$ ) to convergence. ${ }^{29} \mathrm{X}$-seed was employed for the final data presentation and structure plots. ${ }^{31}$ Integrated intensity information for each reflection was obtained by reduction of the data frames with APEX $2 .^{32}$ The integration method employed a three dimensional profiling algorithm and all data were corrected for Lorentz and polarization factors, as well as for crystal decay effects. Finally the data was merged and scaled to produce a suitable data set. SADABS ${ }^{33}$ was used to correct the data for absorption effects. A solution was obtained readily using $\mathrm{XS}^{29}$ as implemented in SHELXTL. Hydrogen atoms bound to carbon were placed in idealized positions, and were set riding on the parent atom. All non-hydrogen atoms were refined with anisotropic thermal parameters.

\section{DNA binding studies}

Electronic absorption spectroscopy. Experiments involving the interaction of nickel(II) hydrazone complexes with DNA were carried out in twice distilled water containing tris(hydroxymethyl)amino methane buffer (Tris, $5 \mathrm{mM}$ ) and $\mathrm{NaCl}$ 
$(50 \mathrm{mM})$ and the $\mathrm{pH}$ was adjusted to 7.2 with hydrochloric acid. A solution of calf thymus DNA (CT DNA) in the above buffer with a ratio of about 1.8-1.9:1 corresponding to the absorptions at 260 and $280 \mathrm{~nm}$ in the UV-visible absorbance indicating the sufficient protein free nature of DNA. ${ }^{34}$ The DNA concentration per nucleotide was determined from the molar extinction coefficient $\left(6600 \mathrm{M}^{-1} \mathrm{~cm}^{-1}\right)$ of the absorption band observed at $260 \mathrm{~nm} .{ }^{35}$ Electronic absorption titration experiments were performed by maintaining the concentration of the metal complex as constant $(25 \mu \mathrm{M})$ but with variable nucleotide concentrations ranging from 0 to $25 \mu \mathrm{M}$. While measuring the absorption spectra, equal amounts of DNA were added to both complex and reference solutions to eliminate the absorbance of DNA itself. The data were then fit into the following equation and the intrinsic binding constant $K_{\mathrm{b}}$ was calculated in each case. ${ }^{36}$

$$
[\mathrm{DNA}] /\left[\varepsilon_{\mathrm{a}}-\varepsilon_{\mathrm{f}}\right]=[\mathrm{DNA}] /\left[\varepsilon_{\mathrm{b}}-\varepsilon_{\mathrm{f}}\right]+1 / K_{\mathrm{b}}\left[\varepsilon_{\mathrm{b}}-\varepsilon_{\mathrm{f}}\right]
$$

where [DNA] is the concentration of DNA in base pairs, $\varepsilon_{\mathrm{a}}$ is the extinction coefficient of the complex at a given DNA concentration, $\varepsilon_{\mathrm{f}}$ is the extinction coefficient of the complex in free solution and $\varepsilon_{\mathrm{b}}$ is the extinction coefficient of the complex when fully bound to DNA. A plot of [DNA] $/\left[\varepsilon_{b}-\varepsilon_{f}\right]$ versus [DNA] gave a slope and an intercept equal to $1 /\left[\varepsilon_{\mathrm{a}}-\varepsilon_{\mathrm{f}}\right]$ and $\left(1 / K_{\mathrm{b}}\right)\left[\varepsilon_{\mathrm{b}}-\varepsilon_{\mathrm{f}}\right]$, respectively. The intrinsic binding constant $K_{\mathrm{b}}$ is the ratio of the slope to the intercept.

Competitive binding fluorescence measurements. The apparent binding constant $\left(K_{\text {app }}\right)$ of the complexes was determined by a fluorescence spectral technique using ethidium bromide (EB) bound CT DNA solution in Tris- $\mathrm{HCl}$ buffer solution ( $\mathrm{pH}, 7.10)$. The changes in fluorescence intensities at $605 \mathrm{~nm}(545 \mathrm{~nm}$ excitation) of EB bound to DNA were measured with respect to different concentrations of the complex. EB was non-emissive in Tris-HCl buffer solution ( $\mathrm{pH}$ 7.10) due to fluorescence quenching of free EB by the solvent molecules. In the presence of DNA, EB showed enhanced emission intensity due to its intercalative binding to DNA. A competitive binding of the metal complexes to CT DNA resulted in the displacement of the bound EB, thereby decreasing its emission intensity. The quenching constant $\left(K_{\mathrm{q}}\right)$ was calculated using the classical Stern-Volmer equation: ${ }^{37}$

$$
I_{0} / I=K_{\mathrm{q}}[\mathrm{Q}]+1
$$

where $I_{0}$ is the emission intensity in the absence of quencher, $I$ is the emission intensity in the presence of quencher, $K_{\mathrm{q}}$ is the quenching constant and $[\mathrm{Q}]$ is the quencher concentration. $K_{\mathrm{q}}$ is the slope, obtained from the plot of $I_{0} / I v s$. [Q]. The apparent binding constant $\left(K_{\text {app }}\right)$ has been calculated from the equation:

$$
\left.K_{\text {EB }}[\mathrm{EB}]=K_{\text {app }} \text { [complex }\right]
$$

The complex concentration was obtained from the value at a $50 \%$ reduction of the fluorescence intensity of EB and $K_{\mathrm{EB}}=1.0 \times 10^{7}$ $\mathrm{M}^{-1},([\mathrm{~EB}]=10 \mu \mathrm{M})$.

\section{Protein binding studies}

Binding of nickel hydrazone complexes with bovine serum albumin (BSA) was studied using fluorescence spectra recorded with an excitation at $280 \mathrm{~nm}$ and corresponding emission at $345 \mathrm{~nm}$ assignable to that of free bovine serum albumin (BSA). The excitation and emission slit widths and scan rates were constantly maintained for all the experiments. Samples were carefully degassed using pure nitrogen gas for $15 \mathrm{~min}$ by using quartz cells (4 $\times 1 \times 1 \mathrm{~cm})$ with high vacuum Teflon stopcocks. Stock solution of BSA was prepared in $50 \mathrm{mM}$ phosphate buffer $(\mathrm{pH}=7.2)$ and stored in the dark at $4{ }^{\circ} \mathrm{C}$ for further use. Concentrated stock solutions of metal complexes were prepared by dissolving them in DMSO : phosphate buffer $(1: 100)$ and diluted suitably with phosphate buffer to get required concentrations. $2.5 \mathrm{ml}$ of BSA solution $(\mu \mathrm{M})$ was titrated by successive additions of a $5 \mu 1$ stock solution of complexes $\left(10^{-4} \mathrm{M}\right)$ using a micropipette. Synchronous fluorescence spectra was also recorded using the same concentration of BSA and complexes as mentioned above with two different $\Delta \lambda$ (difference between the excitation and emission wavelengths of BSA) values such as 15 and $60 \mathrm{~nm}$.

\section{Antioxidant studies}

The free radical scavenging ability of the free hydrazone ligands and nickel(II) complexes were determined against both hydroxyl and superoxide. The hydroxyl radical scavenging activity of the compounds was investigated using the method described by Nash, ${ }^{38}$ whereas superoxide $\left(\mathrm{O}_{2}^{-}\right)$radical scavenging assay was undertaken based on the capacity of the complexes to inhibit formazan formation by scavenging the superoxide radicals generated in the riboflavin-light-NBT system..$^{39}$ For each of the above assays, the tests were run in triplicate by varying the concentration of the complexes, ranging from $10-50 \mu \mathrm{M}$. The percentage activity was calculated by using the formula, $\%$ activity $=\left[\left(A_{0}-A_{\mathrm{C}}\right) / A_{0}\right] \times$ 100 , where $A_{0}$ and $A_{\mathrm{C}}$ represent the absorbance in the absence and presence of the test complex, respectively. The $50 \%$ activity $\left(\mathrm{IC}_{50}\right)$ is calculated from the result of percentage activity.

\section{Cytotoxicity}

In vitro cytotoxicity $\left(\mathrm{IC}_{50}\right)$ was performed on $\mathrm{HeLa}$ (human cervical cancer cells), Hep-2 (human epidermoid cancer cells) and normal NIH 3T3 (mouse embryonic cells) cell lines using the MTT assay method. ${ }^{40}$ Tumour cell lines (HeLa and Hep2) used in this work were grown in Eagles Minimum Essential Medium containing $10 \%$ fetal bovine serum (FBS) and NIH 3T3 fibroblasts were grown in Dulbeccos Modified Eagles Medium (DMEM) containing 10\% FBS. For screening studies, the cells were seeded into 96-well plates in $100 \mu 1$ of respective medium containing $10 \% \mathrm{FBS}$, at plating density of 10000 cells/well and incubated at $37{ }^{\circ} \mathrm{C}, 5 \% \mathrm{CO}_{2}, 95 \%$ air and $100 \%$ relative humidity for $24 \mathrm{~h}$ prior to addition of test compounds. The test compounds were dissolved in dimethylsulfoxide and diluted in respective serum free medium. After $24 \mathrm{~h}, 100 \mu \mathrm{l}$ of the medium containing the test compounds at various concentrations $(0.031,0.062,0.125,0.5$, $1 \mathrm{mM}$ ) was added and incubated at $37{ }^{\circ} \mathrm{C}, 5 \% \mathrm{CO}_{2}, 95 \%$ air and $100 \%$ relative humidity for $48 \mathrm{~h}$. Experiments were carried out in triplicate and the medium containing no test compounds served as a control.

After $48 \mathrm{~h}, 15 \mu \mathrm{l}$ of MTT $\left(5 \mathrm{mg} \mathrm{ml}^{-1}\right)$ in phosphate buffered saline (PBS) was added to each well and incubated at $37^{\circ} \mathrm{C}$ for $4 \mathrm{~h}$. The medium with MTT was then flicked off and the formed formazan crystals were solubilized in $100 \mu \mathrm{l}$ of DMSO and the absorbance at $570 \mathrm{~nm}$ was measured using a micro plate reader. The \% cell inhibition was determined using the following formula and a graph 
Table 1 Crystal structure data of complexes 5, 7 and 8

\begin{tabular}{|c|c|c|c|}
\hline & Complex 5 & Complex 7 & Complex 8 \\
\hline Formula & $\mathrm{C}_{33} \mathrm{H}_{27} \mathrm{~N}_{2} \mathrm{Ni} \mathrm{O}_{2} \mathrm{P}$ & $\mathrm{C}_{33} \mathrm{H}_{27} \mathrm{~N}_{2} \mathrm{Ni} \mathrm{O}_{2} \mathrm{P}$ & $\mathrm{C}_{36} \mathrm{H}_{27} \mathrm{~N}_{2} \mathrm{NiO}_{2} \mathrm{P}$ \\
\hline Molecular weight & 573.25 & 573.25 & 609.28 \\
\hline$\lambda(\AA)$ & 0.71075 & 0.71073 & 1.54178 \\
\hline Crystal system & Triclinic & Triclinic & Monoclinic \\
\hline Space group & $P \overline{1}$ & $P \overline{1}$ & $P 2_{1} / n$ \\
\hline$b(\AA)$ & $\begin{array}{l}11.8729(11) \\
11.9851(11)\end{array}$ & $\begin{array}{l}15.2119(4) \\
17.2447(5)\end{array}$ & $\begin{array}{l}8.8459(14) \\
20488(3)\end{array}$ \\
\hline $\begin{array}{l}c(\mathrm{~A}) \\
\alpha\left(^{\circ}\right)\end{array}$ & $81.516(2)$ & $\begin{array}{l}17.244 /(3) \\
106.718(2)\end{array}$ & $\begin{array}{l}20.488(3) \\
90\end{array}$ \\
\hline$\beta\left({ }^{\circ}\right)$ & $68.128(2)$ & $99.364(2)$ & $98.896(9)$ \\
\hline$\gamma\left({ }^{\circ}\right)$ & $89.718(2)$ & $104.284(2)$ & 90 \\
\hline $\mathrm{Z}$ & 2 & 4 & 4 \\
\hline hkl limits & $-12 \leqslant h \leqslant 12$ & $-16 \leqslant h \leqslant 16$ & $-17 \leqslant h \leqslant 17$ \\
\hline Independent reflections & $4696[R(\mathrm{int})=0.0311]$ & $15259[R(\mathrm{int})=0.042]$ & $4125[R(\mathrm{int})=0.0576]$ \\
\hline Data/restraints/parameters & $4696 / 0 / 200$ & $9357 / 0 / 705$ & $4125 / 0 / 379$ \\
\hline Goodness-of-fit on $\mathrm{F}^{2}$ & 1.072 & 1.016 & 1.052 \\
\hline Final $R$ indices $[I>2 \sigma(I)]$ & $R_{1}=0.0584, \mathrm{w} R_{2}=0.1248$ & $R_{1}=0.0453, \mathrm{w} R_{2}=0.1054$ & $R_{1}=0.0384, \mathrm{w} R_{2}=0.0906$ \\
\hline$R$ indices (all data) & $R_{1}=0.0489, \mathrm{w} R_{2}=0.1179$ & $R_{1}=0.0924, \mathrm{w} R_{2}=0.1302$ & $R_{1}=0.0548, \mathrm{w} R_{2}=0.0960$ \\
\hline
\end{tabular}

was plotted between $\%$ cell inhibition and concentration. From the graph, $\mathrm{IC}_{50}$ values were calculated.

$$
\% \text { Cell inhibition }=100-\mathrm{Abs}_{(\mathrm{drug})} / \mathrm{Abs}_{\text {(control) }} \times 100
$$

\section{Results and discussion}

\section{Description of solid state structures}

The solid-state structure of complexes 5, 7 and $\mathbf{8}$ were analysed by single crystal X-ray studies. Details of the data collection conditions and the parameters of refinement process are given in Table 1. The perspective ORTEP views of complexes 5, 7 and $\mathbf{8}$ with atom numbering schemes are depicted in Fig. 1, 2 and 3, with corresponding selected geometric parameters given in Table 2.

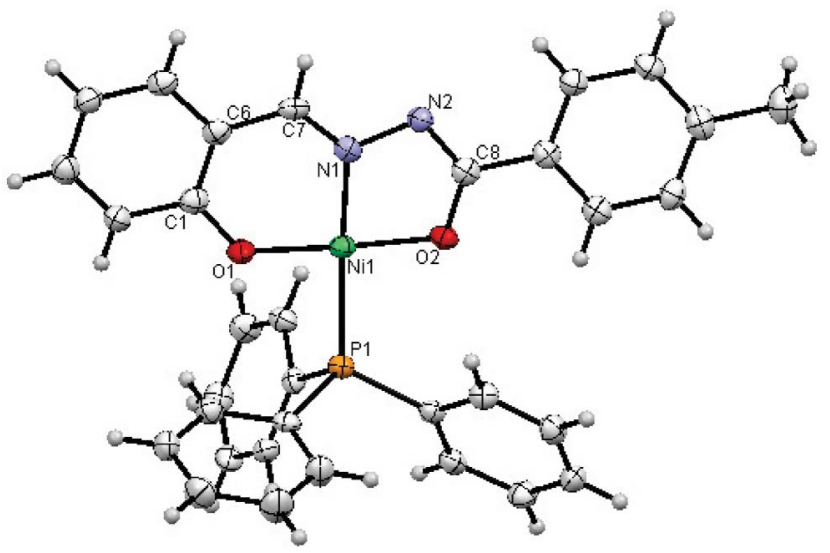

Fig. 1 The molecular structure of complex $\mathbf{5}$, with displacement ellipsoids drawn at the $50 \%$ probability level.
The crystal structures of complexes $\mathbf{5}$ and $\mathbf{8}$ consist of a single molecular unit, while that of complex 7 consists of two molecular units, namely Ni1 and Ni2, which are crystallographically independent but chemically similar. All three complexes 5, 7 and $\mathbf{8}$ possess distorted square planar geometry around the $\mathrm{Ni}(\mathrm{II})$ ion in which the geometric plane is occupied by two oxygen atoms and one nitrogen atom of the respective double negative ONO tridentate hydrazone ligands $\mathbf{1}, \mathbf{3}$ and $\mathbf{4}$, while the fourth coordination site is occupied by the phosphorous atom of triphenylphosphine.

In complex 5, the angles between the phenyl plane of hydrazide (C9-C15) and the $\mathrm{Ni}(\mathrm{II})$ mean coordination plane $(\mathrm{Ni}, \mathrm{O} 1, \mathrm{O} 2$, $\mathrm{N} 1$, P1) are $4.96^{\circ}$, while the corresponding angles between the phenyl planes $(\mathrm{C} 1 \mathrm{~A}-\mathrm{C} 6 \mathrm{~A})$ and $(\mathrm{C} 1 \mathrm{~B}-\mathrm{C} 6 \mathrm{~B})$ and the Ni1 and $\mathrm{Ni} 2$ molecular units of 7 are $6.92^{\circ}$ and $7.01^{\circ}$, respectively. In complex 8, the corresponding angles between the phenyl plane of the hydrazide (C13-C18) and the $\mathrm{Ni}(\mathrm{II})$ mean coordination plane $(\mathrm{Ni}$, $\mathrm{O} 1, \mathrm{O} 2, \mathrm{~N} 1, \mathrm{P} 1)$ are $6.95^{\circ}$. The respective ligand-metal-ligand bite angles, [N1-Ni1-O1] and [N1-Ni1-O2] in single monomeric complexes 5 and 8 are found to be $95.7(1)^{\circ}, 83.5(1)^{\circ}$ and $94.78(9)^{\circ}$ and $83.72(9)^{\circ}$. However, with complex 7, two monomeric units showed their bite angles as $95.54(9)^{\circ}, 84.32(8)^{\circ}, 95.53(9)^{\circ}$ and $84.76(9)^{\circ}$ for [N1A-Ni1-O1A] and [N1B-Ni2-O2B] respectively, which are close to that of the above monomeric unit complexes. The bond distances of Ni-O1[1.820(2)] and Ni-O2 [1.844(2)] in complex $\mathbf{5}$ are larger when compared to those of $\mathrm{Ni}-\mathrm{O} 1 \mathrm{~A}$ [1.802(2)], Ni-O2A [1.830(2)], Ni-O1B [1.796(2)] and Ni-O2B [1.824(2)] in complex 7, and $\mathrm{Ni}-\mathrm{O} 1[1.816(2)]$ and $\mathrm{Ni}-\mathrm{O} 2[1.836(2)]$ in complex 8, suggesting that the bond distances between the central $\mathrm{Ni}(\mathrm{II})$ and the donor atoms are affected by the nature of the substituents in the aroylhydrazone residue and the difference in this case is due to the presence of electron donating group $\left(\mathrm{R}=\mathrm{CH}_{3}\right)$ in complex 5 relative to that of the unsubstituted complex $(\mathrm{R}=\mathrm{H})$ in 7 and $\mathbf{8}^{41}$ However, the bond distance of 


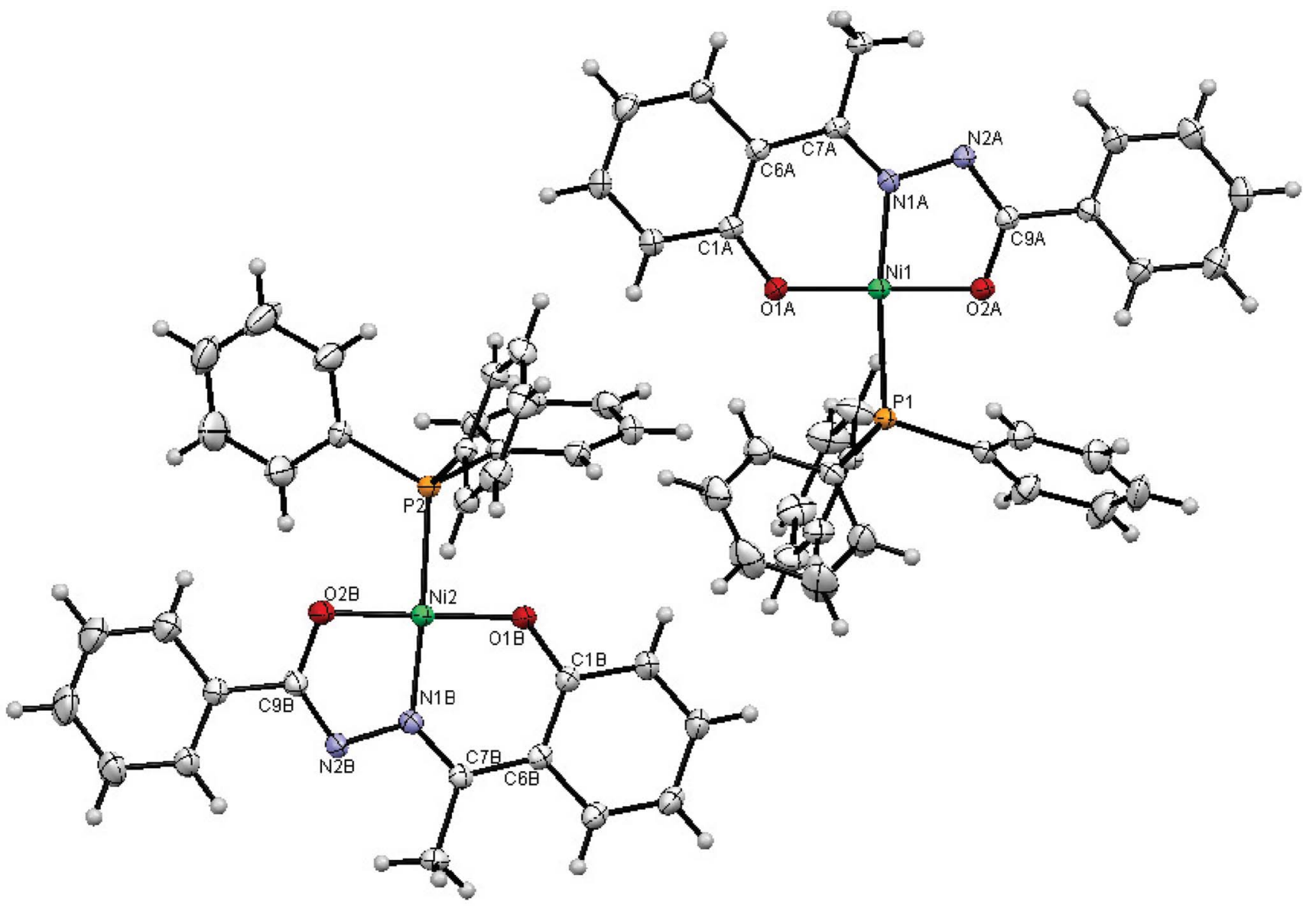

Fig. 2 The molecular structure of 7, with displacement ellipsoids drawn at the $25 \%$ probability level.

Table 2 Selected bond lengths $(\AA)$ and bond angles $\left({ }^{\circ}\right)$

\begin{tabular}{|c|c|c|c|c|c|c|c|c|c|}
\hline \multicolumn{3}{|c|}{$\mathrm{C}_{33} \mathrm{H}_{27} \mathrm{~N}_{2} \mathrm{Ni} \mathrm{O}_{2} \mathrm{P}(\mathbf{5})$} & \multicolumn{4}{|c|}{$\mathrm{C}_{33} \mathrm{H}_{27} \mathrm{~N}_{2} \mathrm{Ni} \mathrm{O}_{2} \mathrm{P}(7)$} & \multicolumn{3}{|c|}{$\mathrm{C}_{36} \mathrm{H}_{27} \mathrm{~N}_{2} \mathrm{Ni} \mathrm{O}_{2} \mathrm{P}(\mathbf{8})$} \\
\hline Ni1-N1 $1.854(2)$ & N1-Ni1-O1 & $95.7(1)$ & Ni1-N1A & $1.869(2)$ & $\mathrm{N} 1 \mathrm{~A}-\mathrm{Ni1}-\mathrm{O} 2 \mathrm{~A}$ & $84.32(4)$ & Ni1-N1 $1.833(2)$ & N1-Ni1-O1 & $94.78(9)$ \\
\hline Ni1-P1 2.226(9) & $\mathrm{O} 2-\mathrm{Ni1}-\mathrm{N} 1$ & $83.5(1)$ & Ni1-P1A & $2.240(8)$ & O1A-Ni1-N1A & $95.54(9)$ & Ni1-P1 2.235(9) & $\mathrm{O} 2-\mathrm{Ni1}-\mathrm{N} 1$ & $83.72(9)$ \\
\hline $\mathrm{C} 1-\mathrm{O} 1 \quad 1.333(5)$ & N1-Ni1-P1 & $174.75(8)$ & $\mathrm{N} 1 \mathrm{~A}-\mathrm{N} 2 \mathrm{~A}$ & $1.405(3)$ & P1-Ni1-N1A & $172.20(6)$ & $\mathrm{C} 1-\mathrm{O} 1 \quad 1.318(3)$ & N1-Ni1-P1 & $177.30(7)$ \\
\hline $1.409(5)$ & $\mathrm{O} 2-\mathrm{Ni1}-\mathrm{O} 1$ & $174.5(1)$ & $\mathrm{O} 2 \mathrm{~A}-\mathrm{C} 9 \mathrm{~A}$ & $1.303(3)$ & $\mathrm{O} 1 \mathrm{~A}-\mathrm{Ni1}-\mathrm{O} 2 \mathrm{~A}$ & $175.56(9)$ & C1-C6 1.404(4) & $\mathrm{O} 2-\mathrm{Ni1}-\mathrm{O} 1$ & $177.86(9)$ \\
\hline $\mathrm{N} 1-\mathrm{N} 2 \quad 1.409(3)$ & $\mathrm{C} 2-\mathrm{C} 1-\mathrm{O} 1-\mathrm{Ni} 1$ & $-175.3(2)$ & N2A-C9A & $1.302(3)$ & P2-Ni2-O1B & $87.64(7)$ & $\mathrm{N} 1-\mathrm{N} 2 \quad 1.407(3)$ & $\mathrm{C} 13-\mathrm{C} 12-\mathrm{O} 2-\mathrm{Nil}$ & $1176.9(2)$ \\
\hline N2-C8 $1.314(5)$ & $\mathrm{C} 9-\mathrm{C} 8-\mathrm{O} 2-\mathrm{Nil}$ & $-178.8(2)$ & Ni1-N1B & $1.855(2)$ & O1B-Ni2-N1B & $95.53(9)$ & N2-C12 1.299(4) & C2-C1-O1-Ni1 & $-179.1(2)$ \\
\hline $1.309(4)$ & & & Nil-O1B & $1.796(2)$ & N1B-Ni2-P2 & $176.82(7)$ & $\mathrm{C} 12-\mathrm{O} 2 \quad 1.319(3)$ & & \\
\hline & & & $\mathrm{Ni1}-\mathrm{O} 2 \mathrm{~B}$ & $1.824(2)$ & $\mathrm{O} 2 \mathrm{~B}-\mathrm{Ni} 2-\mathrm{O} 1 \mathrm{~B}$ & $174.96(9)$ & & & \\
\hline & & & Ni1-P1B & $2.222(8)$ & $\mathrm{C} 6 \mathrm{~A}-\mathrm{C} 7 \mathrm{~A}-\mathrm{N} 1 \mathrm{~A}-\mathrm{N} 2 \mathrm{~A}$ & $176.5(2)$ & & & \\
\hline & & & N1B-N2B & $1.402(3)$ & $\mathrm{N} 1 \mathrm{~A}-\mathrm{N} 2 \mathrm{~A}-\mathrm{C} 9 \mathrm{~A}-\mathrm{C} 10 \mathrm{~A}$ & $177.0(2)$ & & & \\
\hline & & & N1B-C7B & $1.303(3)$ & C7A-N2A-N1A-C9A & $176.5(2)$ & & & \\
\hline
\end{tabular}

$\mathrm{Ni}-\mathrm{N} 1[1.854(2)]$ in $\mathbf{5}$ and $\mathrm{Ni}-\mathrm{N} 1[1.833(2)]$ in $\mathbf{8}$ are lower when compared to that of Ni1-N1A[1.869(2)] and Ni2-N1B[1.855(2)] of complex 7 which may be due to the attachment of the electron releasing $-\mathrm{CH}_{3}$ group on the azomethine carbon in the latter case and the absence of the same in the former cases of $\mathbf{5}$ and $\mathbf{8}$. The $\mathrm{Ni}(\mathrm{II})$ center is shared by one five-membered $\{\mathrm{Ni1N} 1 \mathrm{~N} 2 \mathrm{C} 8 \mathrm{O} 2\}$ and one six membered chelate ring $\{\mathrm{Ni1N} 1 \mathrm{C} 7 \mathrm{C} 6 \mathrm{C} 1 \mathrm{O} 1\}$ in complex $\mathbf{5}$, whereas in 7 it is shared by $\{$ Ni1N1AN2AC9AO2A $\{\mathrm{Ni} 2 \mathrm{~N} 1 \mathrm{BN} 2 \mathrm{BC} 9 \mathrm{BO} 2 \mathrm{~B}\}$ five membered chelate rings and $\{$ Ni1O1AC1AC6AC7AN1A $\} \quad\{$ Ni2O1BC1BC6BC7BN1B $\}$ six membered chelate rings. Similarly, in the case of $\mathbf{8}$, the Ni(II) center is shared by $\{\mathrm{Ni} 1 \mathrm{~N} 1 \mathrm{~N} 2 \mathrm{C} 12 \mathrm{O} 2\}$ five membered ring and 


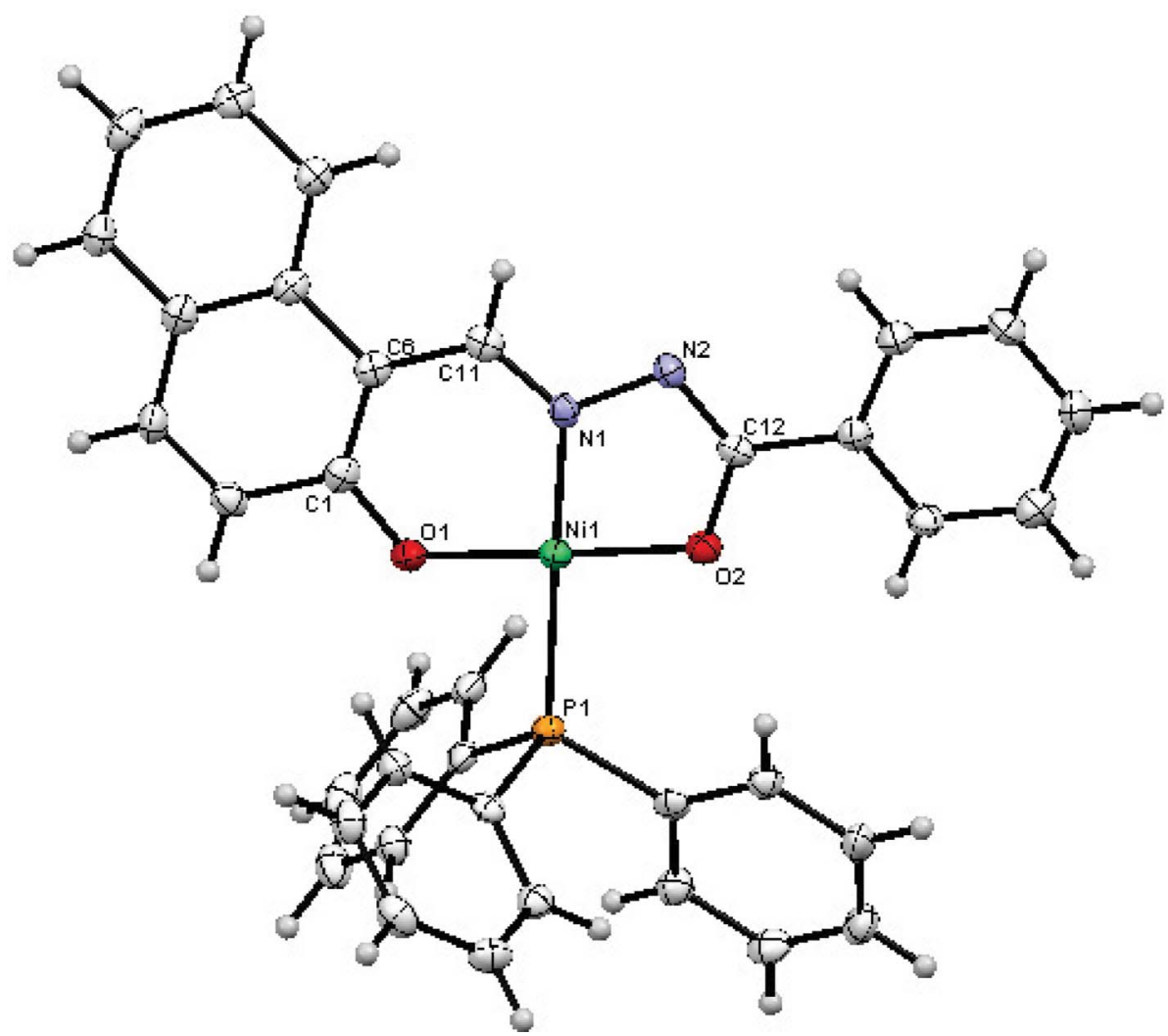

Fig. 3 The molecular structure of $\mathbf{8}$, with displacement ellipsoids drawn at the $50 \%$ probability level.

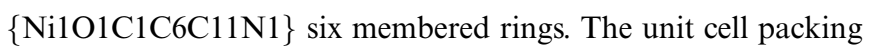
diagrams of the complexes are presented in Fig. S1, S2 and S3, ESI. $\dagger$

\section{DNA binding studies}

\section{UV-visible absorption studies}

The electronic absorption spectra of complexes 5-8 displayed three to five well-resolved bands in the range of 200 to $470 \mathrm{~nm}$ out of which the high energy absorption bands appeared between 250 $300 \mathrm{~nm}$ and another absorption around 320-360 were assigned to the intra-ligand charge transfer transitions of the type $\pi \rightarrow \pi^{*}$ and $n \rightarrow \pi^{*} .{ }^{42}$ Further, the bands appeared around 370 and $420 \mathrm{~nm}$ have been assigned to ligand-to-metal charge transfer (LMCT) as well as metal-to-ligand charge transfer (MLCT) transitions, respectively. ${ }^{43,44}$ A representative electronic absorption spectra of complex 8 without as well as with the added CT DNA is shown in Fig. 4 (similar spectra of complexes 5, $\mathbf{6}$ and $\mathbf{7}$ are presented as S4, S5 and S6 in the ESI $\dagger$ ).

From the electronic absorption spectral data, it was clear that upon increasing the concentration of DNA added to the metal complexes $\mathbf{6 , 7}$ and $\mathbf{8}$, all of the above mentioned absorption bands showed hypochromism accompanied with bathochromic shifts in most of the absorption bands. However, addition of CT DNA to complex $\mathbf{5}$ showed only hypochromism, without any shift suggesting that the nickel hydrazone complexes bind strongly to DNA in an intercalative mode. These observations are similar to those reported earlier for various metallointercalators. ${ }^{45}$ The nature of the shift observed and the percentage of hypochromism

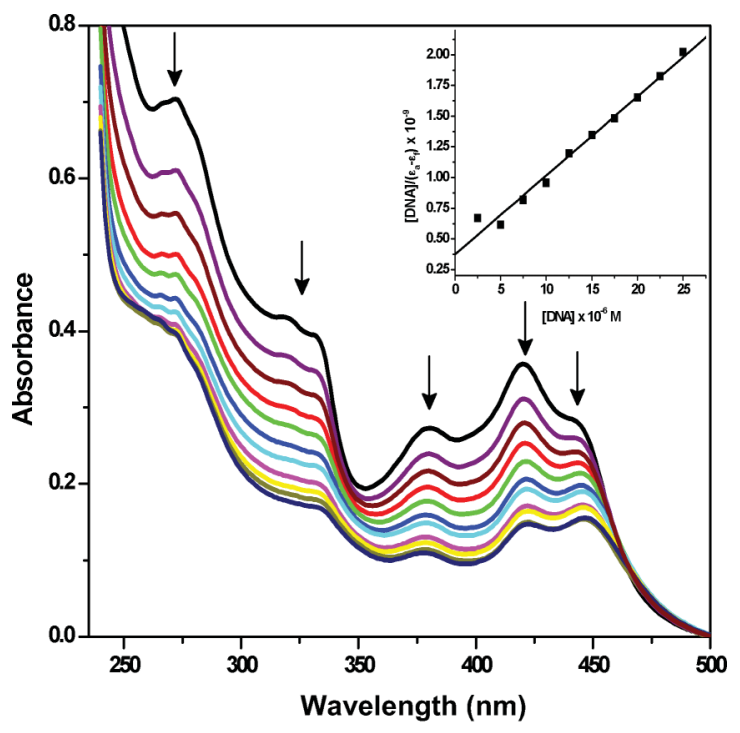

Fig. 4 Electronic absorption spectra of complex $8(25 \mu \mathrm{M})$ in the absence and presence of increasing amounts of CT DNA $(2.5,5.0,7.5,10.0$, $12.5,15.0,17.5$ and $20.0,22.5$ and $25 \mu \mathrm{M}$ ). Arrows show the changes in absorbance with respect to an increase in the DNA concentration (Inset: Plot of [DNA] $v$. [DNA] $\left./\left(\varepsilon_{\mathrm{a}}-\varepsilon_{\mathrm{f}}\right)\right)$.

in the absorption bands in the case of all the complexes after the addition of DNA are given in Table 3.

In order to determine quantitatively the binding strength of the complexes with CT DNA, intrinsic binding constants were obtained by monitoring the changes in both the wavelength, as well 
Table 3 Nature of shift with \% of hypochromism

\begin{tabular}{|c|c|c|c|c|}
\hline Complex & $\begin{array}{l}\text { Absorption wavelength } \\
\text { (nm) (absence of DNA) }\end{array}$ & $\begin{array}{l}\text { Shift of wavelength (nm) } \\
\text { (presence of DNA) }\end{array}$ & Nature of shift & $\%$ of hypochromism \\
\hline \multirow[t]{3}{*}{5} & 305 & - & - & 31.44 \\
\hline & 372 & - & - & 38.85 \\
\hline & 415 & - & - & 36.05 \\
\hline \multirow[t]{4}{*}{6} & 264 & 6 & bathochromic & 41.95 \\
\hline & 303 & 6 & bathochromic & 40.43 \\
\hline & 368 & 3 & bathochromic & 36.33 \\
\hline & 409 & 5 & bathochromic & 30.30 \\
\hline \multirow[t]{4}{*}{7} & 268 & 8 & bathochromic & 85.60 \\
\hline & 308 & 9 & bathochromic & 51.65 \\
\hline & 371 & 3 & bathochromic & 42.90 \\
\hline & 411 & 5 & bathochromic & 32.62 \\
\hline \multirow[t]{5}{*}{8} & 272 & 1 & bathochromic & 43.90 \\
\hline & 330 & 3 & bathochromic & 57.46 \\
\hline & 380 & 2 & bathochromic & 59.86 \\
\hline & 420 & 3 & bathochromic & 58.78 \\
\hline & 441 & 5 & bathochromic & 46.15 \\
\hline
\end{tabular}

as the corresponding intensity of the absorption of the high energy bands of complexes 5, 6, 7 and $\mathbf{8}$ respectively, upon increasing the concentration of added DNA. The following equation was applied to calculate the binding constant: $[\mathrm{DNA}] /\left[\varepsilon_{\mathrm{a}}-\varepsilon_{\mathrm{f}}\right]=[\mathrm{DNA}] /\left[\varepsilon_{\mathrm{b}}-\right.$ $\left.\varepsilon_{\mathrm{f}}\right]+1 / K_{\mathrm{b}}\left[\varepsilon_{\mathrm{b}}-\varepsilon_{\mathrm{f}}\right]$ and the value of the intrinsic binding constant $\left(K_{\mathrm{b}}\right)$ was found to be $4.694 \times 10^{4} \mathrm{M}^{-1}, 7.258 \times 10^{4} \mathrm{M}^{-1}, 7.420 \times 10^{4}$ $\mathrm{M}^{-1}$ and $1.726 \times 10^{5} \mathrm{M}^{-1}$, corresponding to complexes $5, \mathbf{6}, \mathbf{7}$ and $\mathbf{8}$, respectively. The magnitude of the binding constant value clearly showed that complex $\mathbf{8}$ bound more strongly with CT DNA than complexes 5, $\mathbf{6}$ and $\mathbf{7}$ through an intercalative mode.

\section{Competitive binding between EB and complexes for CT DNA}

Generally, steady-state competitive binding experiments using metal complexes as quenchers provide some information about the binding of the complexes to DNA. Ethidium bromide (EB) is a planar cationic dye that is widely used as a sensitive fluorescence probe for native DNA. EB emits intense fluorescent light in the presence of DNA due to its strong intercalation between the adjacent DNA base pairs. This displacement technique is based on the decrease of fluorescence intensity resulting from the displacement of bound EB from a DNA sequence by a quencher and the quenching is due to the reduction of the number of binding sites on the DNA that is available to the EB. Hence, this method serves as indirect evidence to identify intercalative binding modes. In our study, changes in the intensity as well as the position of the emission band of EB bound DNA were monitored after the addition of metal complex solution. The above said emission band in the spectra of combined nickel hydrazone complexDNA system showed a significant bathochromic shift with a simultaneous reduction in the fluorescence intensity $(34.76 \%$, $36.51 \%, 36.85 \%$ and $39.26 \%$, respectively) revealing that the EB molecules are displaced from their DNA binding sites by the added complexes.

The fluorescence spectrum of EB bound-DNA quenched by complex 8 is shown in Fig. 5 (respective spectra of complexes 5, 6 and 7 are presented as S7, S8 and S9 in the ESI $\dagger$ ) with the SternVolmer plot as an inset to the figures. The observed linearity in the plot supported the fact that the quenching of EB bound to DNA by the test complex is in good agreement with the linear Stern-Volmer

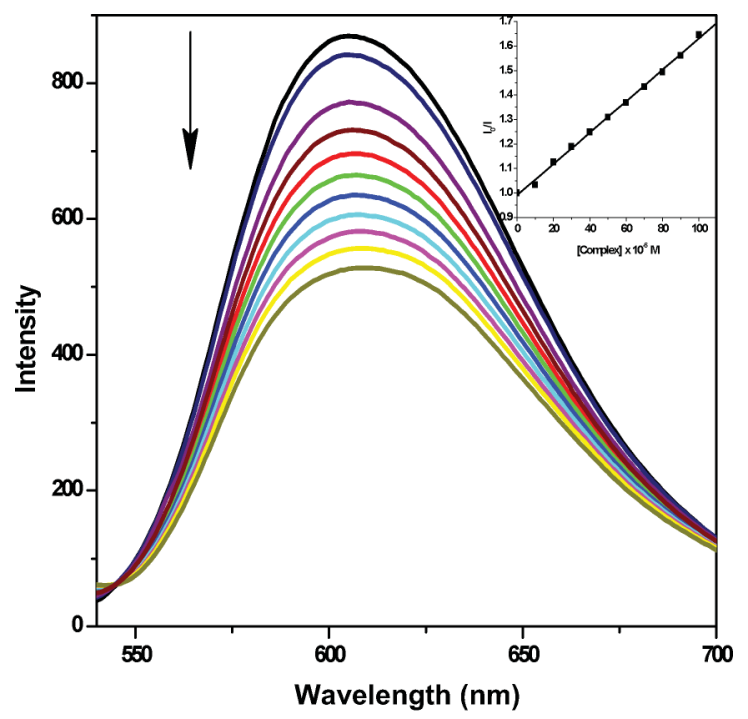

Fig. 5 Emission spectra of DNA-EB $(10 \mu \mathrm{M})$, in the presence of $0,10,20$, $30,40,50,60,70,80,90$ and $100 \mu \mathrm{M}$ of complex 8 . The arrow indicates the changes in the emission intensity as a function of complex concentration. Inset: Stern-Volmer plot of the fluorescence titration data corresponding to complex 8 .

equation. The calculated apparent binding constant values, $K_{\text {app}}$, corresponding to different nickel hydrazone complexes 5-8 was $5.423 \times 10^{5} \mathrm{M}^{-1}, 5.622 \times 10^{5} \mathrm{M}^{-1}, 5.762 \times 10^{5} \mathrm{M}^{-1}$ and 6.380 $\times 10^{5} \mathrm{M}^{-1}$ respectively, whereas the quenching constant $K_{\mathrm{q}}$ was determined to be $5.730 \times 10^{3} \mathrm{M}^{-1}, 5.746 \times 10^{3} \mathrm{M}^{-1}, 6.215 \times 10^{3}$ $\mathrm{M}^{-1}$ and $6.584 \times 10^{3} \mathrm{M}^{-1}$. This data showed the higher quenching efficiency of complex 8 compared to that of the other complexes under investigation, reflecting a strong binding of the former with DNA than the rest of the complexes, similar to the results of the absorption spectral study.

\section{Protein binding studies}

\section{Fluorescence quenching of BSA by metal complexes (5-8)}

Qualitative analysis of the binding of chemical compounds to BSA is generally detected by examining its fluorescence spectra. 
Generally, the fluorescence of a protein is caused by three intrinsic characteristics of the protein, namely tryptophan, tyrosine, and phenylalanine residues. Fluorescence quenching refers to any process that reduces the fluorescence intensity of the fluorophore due to a variety of molecular interactions such as excited-state reactions, molecular rearrangement, energy transfer ground-state complex formation and collision quenching. Fig. 6 shows the effect of increasing the concentration of added complex $\mathbf{8}$ on the fluorescence emission of BSA (for complexes 5-7, see S10, S11 and S12, ESI $\dagger$ ). Addition of respective nickel hydrazone complexes to BSA resulted in the quenching of fluorescence emission intensity along with a hypsochromic shift of 6 to $8 \mathrm{~nm}$, revealing quenching due to the complex formed between the nickel(II) hydrazone chelates and BSA.

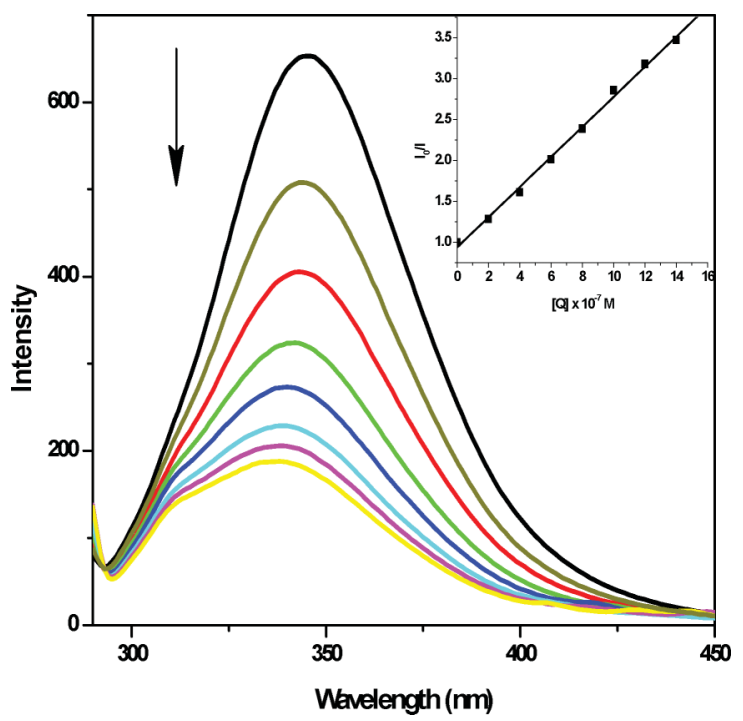

Fig. 6 Emission spectrum of BSA $\left(1 \times 10^{-6} \mathrm{M} ; \lambda_{\text {exi }}=280 \mathrm{~nm} ; \lambda_{\text {emi }}=345\right.$ $\mathrm{nm})$ as a function of concentration of complex $\mathbf{8}(0,2,4,6,8,10,12$ and $\left.14 \times 10^{-7} \mathrm{M}\right)$. The arrow indicates the effect of metal complex 8 on the fluorescence emission of BSA.

The fluorescence quenching is described by the Stern-Volmer relation,

$$
I_{0} / I=1+K_{\mathrm{Sv}}[\mathrm{Q}]
$$

where $I_{0}$ and $I$ are the fluorescence intensities of the fluorophore in the absence and presence of quencher, $K_{\mathrm{SV}}$ is the Stern-Volmer quenching constant and $[\mathrm{Q}]$ is the quencher concentration. The $K_{\mathrm{Sv}}$ value obtained as a slope from the plot of $I_{0} / I v s$. $[\mathrm{Q}]$ in respect to complexes 5, 6, 7 and 8 were found to be $1.256 \times 10^{6} \mathrm{M}^{-1}, 1.727$ $\times 10^{6} \mathrm{M}^{-1}, 1.788 \times 10^{6} \mathrm{M}^{-1}$ and $1.839 \times 10^{6} \mathrm{M}^{-1}$, respectively.

Quenching can occur by different mechanisms which are usually classified as dynamic quenching and static quenching. Dynamic quenching refers to a process in which the fluorophore and the quencher come into contact during the transient existence of the excited state, while static quenching refers to fluorophorequencher complex formation in the ground state. A simple method to differentiate between the above types of quenching is UV-visible absorption spectroscopy. The absorption band obtained in the spectra of BSA at $278 \mathrm{~nm}$ in the absence of metal complexes showed an increase in the intensity without any shift after the addition of all the complexes except complex $\mathbf{8}$, whereupon a similar behaviour of intensity increase with a slight hypsochromic shift was observed, revealing that there exists a static interaction between BSA and the added complexes due to the formation of a ground state complex of the type BSA-metal complex as reported earlier. ${ }^{46} \mathrm{~A}$ representative absorption spectrum of pure BSA and BSA-complex 8 is shown in Fig. 7 (for complexes 5-7, see S13, S14 and S15, ESI $\dagger$ ).

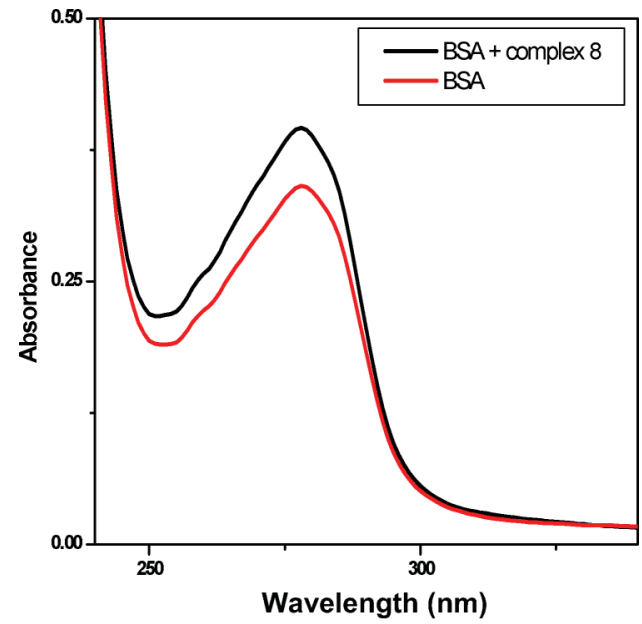

Fig. 7 The absorption spectra of BSA $\left(1 \times 10^{-5} \mathrm{M}\right)$ and BSA-Complex 8 $\left(\mathrm{BSA}=1 \times 10^{-5} \mathrm{M}\right.$ and Complex $\left.8=1 \times 10^{-6} \mathrm{M}\right)$.

\section{Binding constant and number of binding sites}

When small molecules bind independently to a set of equivalent sites on a macromolecule, the equilibrium between free and bound molecules is represented by the Scatchard equation: ${ }^{47,48}$

$$
\log \left[F_{0}-F / F\right]=\log K+n \log [\mathrm{Q}]
$$

where $K$ and $n$ are the binding constant and the number of binding sites, respectively.

Thus, a plot of $\log \left(F_{0}-F\right) / F$ versus $\log [\mathrm{Q}]$ (Fig. 8) can be used to determine the values of both $K$ and $n$ and such values calculated for complexes 5-8 are listed in Table 4.

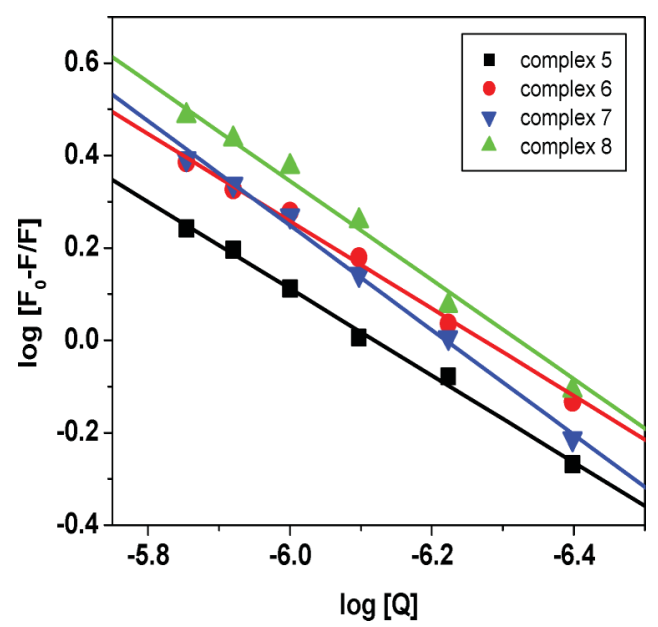

Fig. 8 Plot of $\log \left[\left(F_{0}-F\right) / F\right]$ vs. $\log [\mathrm{Q}]$.

From the values of $n$, it is inferred that there is only one independent class of binding sites for complexes on BSA and also a direct relation between the binding constant and number of binding sites. 
Table 4 Binding constant and number of binding sites for the interactions of nickel hydrazone complexes 5-8 with BSA

\begin{tabular}{lll}
\hline System & $K\left(\mathrm{M}^{-1}\right)$ & $n$ \\
\hline BSA + complex 5 & $5.670 \times 10^{5}$ & 0.9403 \\
BSA + complex 6 & $8.300 \times 10^{5}$ & 0.9442 \\
BSA + complex 7 & $1.221 \times 10^{6}$ & 1.0232 \\
BSA + complex 8 & $1.086 \times 10^{7}$ & 1.1312 \\
\hline
\end{tabular}

The results of binding experiments clearly proved that among complexes $\mathbf{5}$ and $\mathbf{6}$, the later showed stronger binding with both DNA and BSA compared to the former, which can be attributed to the presence of an electron releasing methyl group at the azomethine carbon of the coordinated hydrazone ligand in complex 6. The electron releasing nature of the $\mathrm{CH}_{3}$ group towards the $\mathrm{Ni}$ ion through the coordinated azomethine nitrogen in complex 6 may assist the respective interactions between the complex and either DNA or protein. However, complex 7, containing a coordinated hydrazone possessing similar methyl substitution at the azomethine carbon but with a lack of $\mathrm{CH}_{3}$ substitution at the phenyl ring of the acid hydrazide portion, exhibited greater binding with DNA and proteins than complexes 5 and 6, which may be due to the greater planarity of complex 7 . In the case of complex $\mathbf{8}$, containing the coordinated hydrazone with substitution of a phenyl ring in the carbonyl carbon with a napthyl group, showed the highest level of binding among all complexes in this study. The higher binding affinity of complex $\mathbf{8}$ towards both CT DNA and BSA could be explained in terms of the planarity of the ligand coordinated to nickel. ${ }^{49,50}$ The overall order of interaction between the complexes and CT DNA as well as BSA decreased in the order $8>7>6>5$.

\section{Characteristics of synchronous fluorescence spectra}

Synchronous fluorescence spectrum provides information on the molecular microenvironment, particularly in the vicinity of the fluorophore functional groups. ${ }^{51}$ It is well known that the fluores- cence of BSA may be due to the presence of tyrosine, tryptophan and phenylalanine residues and hence spectroscopic methods are usually applied to study the conformation of serum proteins. According to Miller, ${ }^{52}$ in synchronous fluorescence spectroscopy, the difference between excitation and emission wavelength $\left(\Delta \lambda=\lambda_{\text {emi }}\right.$ $-\lambda_{\text {exc }}$ ) reflects the spectra of a different nature of chromophores, with large $\Delta \lambda$ values such as $60 \mathrm{~nm}$, the synchronous fluorescence of BSA is characteristic of tryptophan residue and the small $\Delta \lambda$ values such as $15 \mathrm{~nm}$ is characteristic of tyrosine. ${ }^{53}$ To explore the structural changes of BSA due to the addition of nickel(II) hydrazone complexes, we measured synchronous fluorescence spectra with respect to addition of complexes 5-8. The synchronous fluorescence spectra of BSA with various concentrations of metal complexes were recorded at both $\Delta \lambda=15 \mathrm{~nm}$ and $60 \mathrm{~nm}$. Upon increasing the concentration of nickel hydrazone complexes, the intensity of emission corresponding to tryptophan was found to decrease with a hypsochromic shift of emission wavelength. The representative spectrum of complex 8 is given in Fig. 9 (for complexes 5, 6 and 7, see S16, S17 and S18, ESI $\dagger$ ).

At the same time, the tyrosine fluorescence emission showed very little decrease in the intensity without a significant change in the position of the emission band. These experimental results indicate that the metal complex does not affect the microenvironment of tyrosine residues during the binding process and the polarity around the tryptophan residues is decreased and the hydrophobicity around the tryptophan residues is strengthened. The hydrophobicity observed in fluorescence and synchronous measurements confirmed the effective binding of all the complexes with the BSA.

\section{Antioxidant}

The radical scavenging property of hydrazone derivatives have attracted the interest of researchers and are thus investigated in in vitro systems. ${ }^{54,55}$ Both the hydroxyl $(\mathrm{OH})$ and superoxide $\left(\mathrm{O}_{2}^{-}\right)$radicals are clinically important reactive species produced in

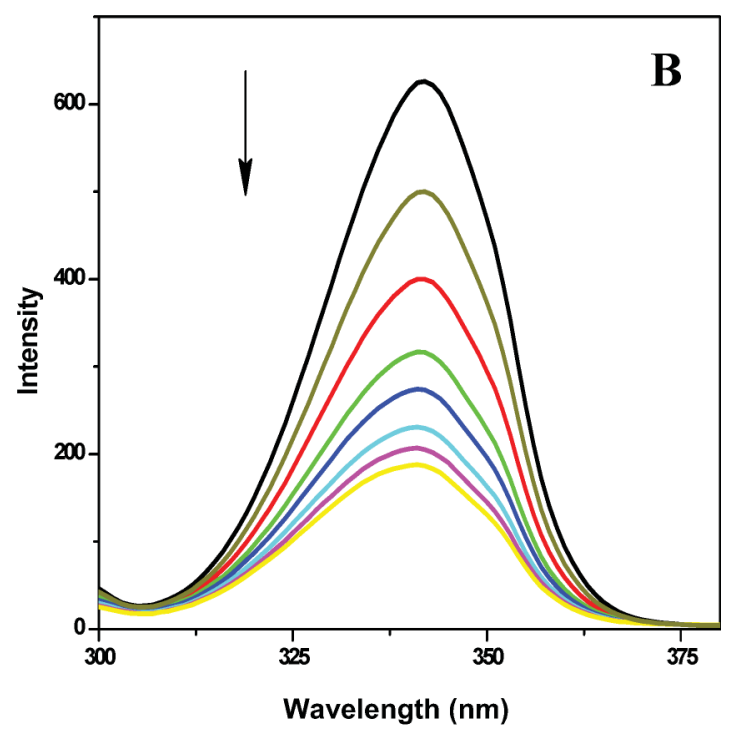

Fig. 9 Synchronous spectra of BSA $\left(1 \times 10^{-6} \mathrm{M}\right)$ as a function of concentration of complex $8\left(0,2,4,6,8,10,12\right.$ and $\left.14 \times 10^{-7} \mathrm{M}\right)$ with a wavelength difference of $\Delta \lambda=15 \mathrm{~nm}$ (A) and $\Delta \lambda=60 \mathrm{~nm}$ (B). The arrow indicates the decrease in emission intensity accompanied by hypochromic shift (B) w.r.t various concentration of complex $\mathbf{8}$. 
most organ systems and participate in various physiological and pathophysiological processes, such as carcinogenesis, aging, viral infection, inflammation, among others. ${ }^{56,57}$ Hence, the antioxidant properties of the ligands (1-4) and corresponding nickel(II) complexes (5-8) were studied towards the above mentioned radicals and compared with the standard antioxidant butylated hydroxy anisole (BHA).

Fig. 10 shows the plot of the hydroxyl radical scavenging effect (\%) and it is found that the inhibitory effect of the compounds tested with $\mathrm{OH}$ and $\mathrm{O}_{2}{ }^{-}$radicals are concentration dependent and their suppression ratio increases with increasing sample concentrations in the tested range. The $\mathrm{IC}_{50}$ values exhibited by ligands 1-4 to scavenge hydroxyl radicals are 57.81, 53.65, 50.1 and $38.55 \mu \mathrm{M}$, respectively, whereas for superoxide radicals the $\mathrm{IC}_{50}$ values are found to be $41.95,41.92,39.51$ and $36.84 \mu \mathrm{M}$ in the order of $\mathbf{1}>\mathbf{2}>\mathbf{3}>\mathbf{4}$. The $\mathrm{IC}_{50}$ values of newly synthesised nickel(II) complexes containing the above ligands against $\mathrm{OH}$ and $\mathrm{O}_{2}{ }^{-}$radicals are found to be 27.74, 24.42, 21.37, 20.09, 26.82, 23.75, 21.06 and $18.19 \mu \mathrm{M}$ with the order of $\mathbf{5}>\mathbf{6}>\mathbf{7}>\mathbf{8}$. From the above values, it is found that all of the metal complexes and ligands tested in this study behaved as more effective inhibitors than the standard scavenging agent, butylated hydroxy anisole (BHA) for $\mathrm{OH}$ and $\mathrm{O}_{2}^{-}$radicals.

In general, the antioxidant activity of $\mathrm{Ni}(\mathrm{II})$ complexes as well as free ligands against the free radicals $\mathrm{OH}$ and $\mathrm{O}_{2}^{-}$, decreased in the order $8>7>6>5>4>3>2>1$. However, the radical scavenging effects of nickel chelates are higher than that of the corresponding free ligands due to chelation with nickel ions in complexation that exert different and selective effects on scavenging radicals of the biological system. Among all the ligands and their corresponding nickel complexes, the one possessing a more planar hydrazone moiety ie., complex $\mathbf{8}$ containing ligand $\mathbf{4}$, showed greater potential scavenging activity than the rest of the complexes with their respective ligands. Further, the results obtained for the different radicals confirmed that the complexes are more effective at arresting the formation of $\mathrm{O}_{2}{ }^{-}$than $\mathrm{OH}$ radicals. Hence, we strongly believe that the present metal hydrazone complexes can be further evaluated as suitable candidates leading to the development of new potential antioxidants and therapeutic reagents for some diseases.

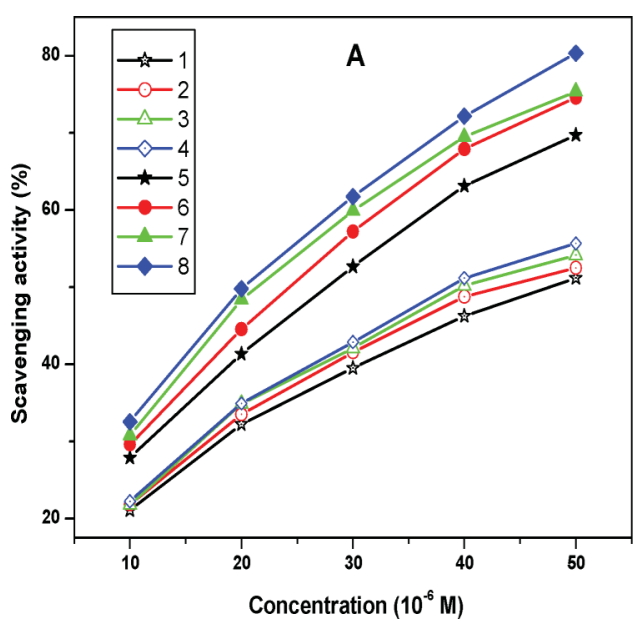

\section{Cytotoxicity}

Preliminary up-to-date results are extremely positive, thus supporting our facts and confirming the enormous potential of this class of Ni(II) complexes as anticancer agents. Nickel hydrazone complexes 5-8 were evaluated for their cytotoxicity against NIH 3T3 normal cell lines and HeLa and Hep-2 tumour cell lines by colorimetric assays (MTT assay) in which mitochondrial dehydrogenase activity was measured as an indication of cell viability. Complexes 5-8 were dissolved in DMSO and blank samples containing the same amount of DMSO were taken as controls. The effects of the complexes on the viability of these cells evaluated after an exposure period of $48 \mathrm{~h}$ showed antitumour activity and their corresponding $\mathrm{IC}_{50}$ values, related to inhibition of tumour cell growth at the $50 \%$ level, are noted.

Surprisingly, complexes 5, 6 and $\mathbf{7}$ completely failed to arrest the growth of both HeLa and Hep-2 cells, even up to a concentration of $1000 \mu \mathrm{M}$. However, complex $\mathbf{8}$ showed a significant, concentration dependent, activity in arresting the growth of the selected cells. Upon increasing the concentration of complex 8 (Fig. 11) from $63 \mu \mathrm{M}$ to $1000 \mu \mathrm{M}$, an increase in the percentage of cell inhibition

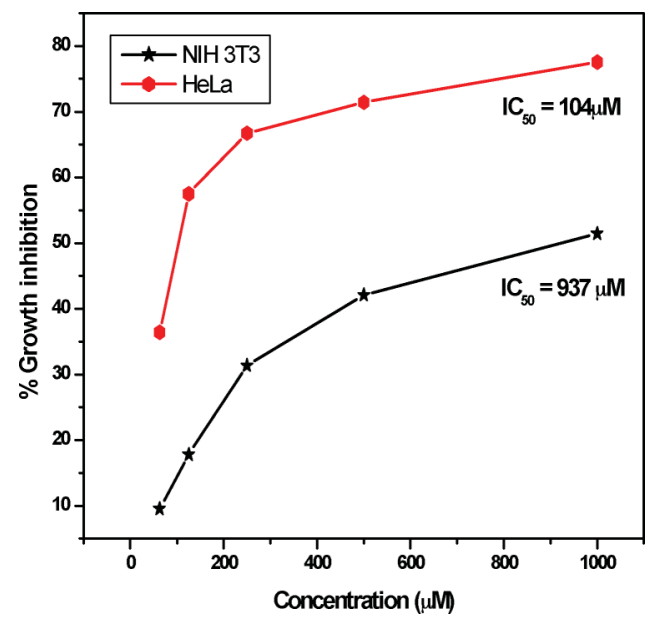

Fig. $11 \%$ inhibition of NIH 3 T3 and HeLa cell lines as a function of concentration of complex $\mathbf{8}$.

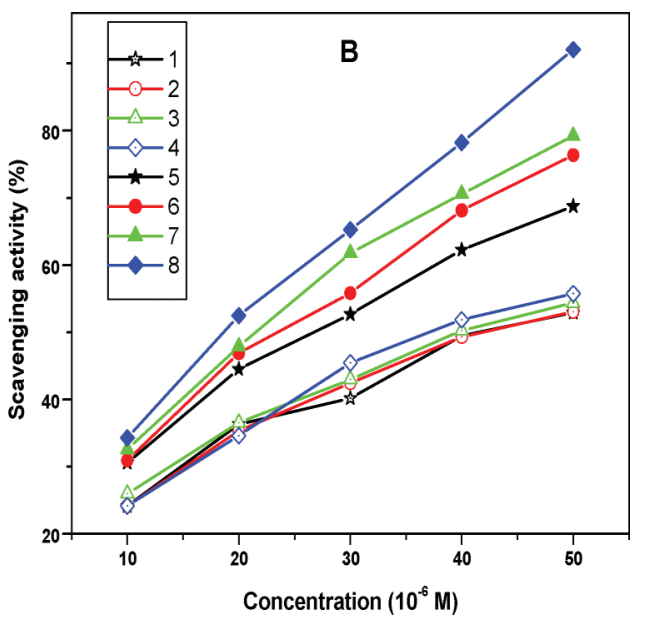

Fig. 10 Trends in the inhibition of $\mathrm{OH}(\mathrm{A})$ and $\mathrm{O}_{2}^{-}$(B) radicals by ligands 1, 2, 3 and 4 and the corresponding metal complexes 5, 6, 7 and 8 at variable concentrations. 
was observed, with respective $\mathrm{IC}_{50}$ values of $104 \mu \mathrm{M}$ and $>500 \mu \mathrm{M}$ for HeLa and Hep-2 cells (data not presented in Fig. 11) and they are comparable with that of earlier report. ${ }^{58}$ Hence, it is clear that complex $\mathbf{8}$ selectively arrested the growth of HeLa cells only. A simple structure activity relationship suggest that among the investigated complexes, complex $\mathbf{8}$, which contains a coordinated hydrazone with a more planar napthyl group, is responsible for the selectivity and the potential inhibition against the tumour cells. All complexes did not cause any damage to the healthy cells (NIH 3T3) (complex 8: $\mathrm{IC}_{50}=937 \mu \mathrm{M}$ ), indicating that they are non-toxic to normal cells, as expected for a better drug.

\section{Conclusion}

In this work, a systematic approach to the synthesis of four new bivalent nickel complexes containing double negative tridentate ONO chelating hydrazone ligands, differing in the nature of substitution and planarity, is presented. The structure and geometry of the complexes analysed through single crystal X-ray diffraction revealed square planar geometry around the $\mathrm{Ni}(\mathrm{II})$ ion, with a slight distortion in complexes 5,7 and $\mathbf{8}$. From the bio-inorganic chemistry point of view, binding interaction of all the newly synthesised complexes with CT DNA and BSA protein has been carried out. Binding experiments revealed that the nature of the substitution group and planarity of the hydrazone coordinated to the nickel ion in the complexes showed a pronounced effect on their binding ability with both DNA and proteins. Also, the antioxidant and cytotoxicity properties of the newly synthesised complexes showed that they can be investigated in detail as potential drugs. Among the complexes synthesised in this work, complex 8 , which possesses a more planar napthyl unit instead of the phenyl ring available in the other complexes, showed greater efficiency at arresting the growth of cancer cells, as well as in inhibiting the production of free radicals.

From the results obtained in various biological studies, it became clear that among complexes 5, 6, 7 and $\mathbf{8}$, the one (complex 8) that possesses a more planar napthyl unit instead of the phenyl ring available in other complexes $(5,6$ and 7$)$ showed higher efficiency. Hence, we believe that detailed in vivo experiments utilizing these nickel hydrazone complexes could lead to a significant outcome in further expanding their scope.

\section{Acknowledgements}

We sincerely thank the University Grants Commission, New Delhi, India for the award of a Fellowship in Science for Meritorious Students (RFSMS) to P. Krishnamoorthy under the UGC-SAP-DRS programme. AHC is grateful to the Robert A. Welch Foundation (Grant F-0003) for financial support of this work.

\section{References}

1 R. McRae, P. Bagchi, S. Sumalekshmy and C. J. Fahrni, Chem. Rev., 2009, 109, 4780-4827.

2 E. V. Bichenkova, X. Yu, P. Bhadra, H. Heissigerova, S. J. A. Pope and B. J. Coe, Inorg. Chem., 2005, 44, 4112-4114.

3 F. Westerlund, L. M. Wilhelmsson, B. Norden and P. Lincoln, J. Phys. Chem. B, 2005, 109, 21140-21144.

4 G. O. Ahn, K. J. Botting, A. V. Patterson, D. C. Ware, M. Tercel and W. R. Wilson, Biochem. Pharmacol., 2006, 71, 1683-1694.
5 A. A. Tak, F. Arjmand and S. Tabassum, Transition Met. Chem., 2002, 27, 741-747.

6 N. Valls, I. Usón, C. Gouyette and J. A. Subirana, J. Am. Chem. Soc., 2004, 126, 7812-7816.

7 S. Arounaguiri and B. G. Maiya, Inorg. Chem., 1996, 35, 4267-4270.

8 Q. L. Zhang, J. G. Liu, J. Liu, G. Q. Xue, H. Li and J. Z. Liu et al., J. Inorg. Biochem., 2001, 85, 291-296.

9 K. C. Skyrianou, C. P. Raptopoulou, V. Psycharis, D. P. Kessissoglou and G. Psomas, Polyhedron, 2009, 28, 3265-3271.

10 Y. Jin, M. A. Lewis, N. H. Gokhale, E. C. Long and J. A. Cowan, J. Am. Chem. Soc., 2007, 129, 8353-8361.

11 F. Bisceglie, M. Baldini, M. Belicchi-Ferrari, E. Buluggiu, M. Careri, G. Pelosi, S. Pinelli and P. Tarasconi, Eur. J. Med. Chem., 2007, 42, 627-634.

12 G. Barone, N. Cambino, A. Ruggirello, A. Silvestri, A. Terenzi and V. T. Liveri, J. Inorg. Biochem., 2009, 103, 731-737.

13 S. S. Matkar, L. A. Wrischnik, P. R. Jones and U. Hellmann-Blumberg, Biochem. Biophys. Res. Commun., 2006, 343, 754-761.

14 K. S. Kasprzak, Chem. Res. Toxicol., 1991, 4, 604-615.

15 R. B. Ciccarelli and K. E. Wetterhahn, Cancer Res., 1984, 44, 3892 3897.

16 R. B. Ciccarelli and K. E. Wetterhahn, Cancer Res., 1982, 42, 3544 3549.

17 R. B. Ciccarelli, R. H. Hampton and K. W. Jennette, Cancer Lett., 1981, 12, 349-354.

18 L. Jiaquin, T. Jianniao, J. Zhang, Z. Hu and C. Xingguo, Anal. Bioanal. Chem., 2003, 376, 864-867.

19 J. S. Stamler, D. J. Singel and J. Loscalzo, Science, 1992, 258, 1898-1902.

20 H. Y. Shrivastava, M. Kanthimathi and B. U. Niar, Biochem. Biophys. Res. Commun., 1999, 265, 311-314.

21 S. J. Lan, T. P. A. Kruck and B. Sarkar, J. Biol. Chem., 1974, 249, $5878-5884$

22 C. Tanford, J. Am. Chem. Soc., 1952, 74, 211-215.

23 H. A. Saroof and H. J. Mark, J. Am. Chem. Soc., 1953, 75, 1420-1426.

24 F. Friedberg, FEBS Lett., 1975, 59, 140-141.

25 M. C. Beinfield, D. A. Bryce, D. Kahavy and A. Mortonosi, J. Biol. Chem., 1975, 250, 6282-6287.

26 B. K. Jin and L. P. Lu, Chin. Chem. Lett., 2001, 12, 989-992.

27 N. S. Quiming, R. B. Vergel, M. G. Nicolas and J. A. Villanueva, J. Health Sci., 2005, 51, 8-15.

28 L. M. Venanzi, J. Chem. Soc., 1958, 719-724.

29 G. M. Sheldrick, Acta Crystallogr., Sect. A: Found. Crystallogr., 2008, 64, 112-122.

30 A. L. Spek, Acta Crystallogr., Sect. D: Biol. Crystallogr., 2009, 65, $148-155$.

31 L. J. Barbour, J. Supramol. Chem., 2001, 1, 189-191.

32 APEX2, Program for Data Collection and Integration on Area Detectors, BRUKER AXS Inc, 5465, East Cheryl Parkway, Madison, WI 537115373, USA.

33 G. M. Sheldrick, SADABS (version 2008/1), Program for Absorption Correction for Data from Area Detector Frames, University of Gottingen, 2008.

34 J. Marmur, J. Mol. Biol., 1961, 3, 208-218.

35 M. E. Reichmann, S. A. Rice, C. A. Thomas and P. Doty, J. Am. Chem. Soc., 1954, 76, 3047-3053.

36 A. Wolfe, G. H. Shimer and T. Meehan, Biochemistry, 1987, 26, 63926396.

37 M. Lee, A. L. Rhodes, M. D. Wyatt, S. Forrow and J. A. Hartley, Biochemistry, 1993, 32, 4237-4245.

38 T. Nash, Biochem. J., 1953, 55, 416-421.

39 C. Beauchamp and I. Fridovich, Anal. Biochem., 1971, 44, 276-287.

40 M. Blagosklonny and W. S. EI-diery, Int. J. Cancer, 1996, 67, 386392.

41 N. M. H. Salem, L. El-Sayed, S. Foro, W. Haase and M. F. Iskander, Polyhedron, 2007, 26, 4161-4172.

42 K. Chichak, U. Jacquenard and N. R. Branda, Eur. J. Inorg. Chem., 2002, 357-368.

43 T. Ghosh, B. Mondal, Tarun Ghosh, M. Sutradhar, G. Mukherjee and M. G. B. Drew, Inorg. Chim. Acta, 2007, 360, 1753-1761.

44 M. Kandaz, I. Yilmaz, S. Keskin and A. Koca, Polyhedron, 2002, 21, $825-834$.

45 W. J. Mei, J. Liu, K. C. Zheng, L. J. Lin, H. Chao, A. X. Li, F. C. Yun and L. N. Ji, Dalton Trans., 2003, 1352-1359.

46 Y. Hu, Y. Yang, C. Dai, Y. Liu and X. Xiao, Biomacromolecules, 2010, 11, 106-112. 
47 J. R. Lakowicz, Fluorescence Quenching: Theory and Applications. Principles of Fluorescence Spectroscopy, Kluwer Academic/Plenum Publishers, New York, 1999, pp. 53-127.

48 X. Z. Feng, Z. Yang, L. J. Wang and C. Bai, Talanta, 1998, 47, $1223-$ 1229.

49 S. Ramakrishnan, V. Rajendiran, M. Palaniandavar, V. S. Periasamy, B. S. Srinag, H. Krishnamurthy and M. A. Akbarsha, Inorg. Chem., 2009, 48, 1309-1322.

50 V. Rajendiran, M. Murali, E. Suresh, M. Palaniandavar, V. S. Periasamy and M. A. Akbarsha, Dalton Trans., 2008, 2157-2170.

51 G. Z. Chen, X. Z. Huang, J. G. Xu, Z. Z. Zheng and Z. B. Wang, Methods of Fluorescence Analysis, second ed., Science Press, Beijing, 1990.
52 J. N. Miller, Proc. Anal. Div. Chem. Soc., 1979, 16, 203-208.

53 J. H. Tang, F. Luan and X. G. Chen, Bioorg. Med. Chem., 2006, 14, 3210-3217.

54 Yong Li, Zheng-Yin Yang and Ming-Fang Wang, Eur. J. Med. Chem., 2009, 44, 4585-4595.

55 Bao-dui Wang, Zheng-Yin Yang, Patrick Crewdson and Da-qi wang, J. Inorg. Biochem., 2007, 101, 1492-1504.

56 S. Satyanarayana, J. C Dabrowiak and J. B. Chaires, Biochemistry, 1993, 32, 2573-2584.

57 A. M. Pyle, J. P. Rehmann, R. Meshoyrer, C. V. Kumar, N. J. Turro and J. K. Barton, J. Am. Chem. Soc., 1989, 111, 3051-3058.

58 Zeng-Chen Liu, Bao-Dui Wang, Bo Li, Qin Wang, Zheng-Yin Yang, Tian-Rong Li and Yong Li, Eur. J. Med. Chem., 2010, 45, 5353-5361. 